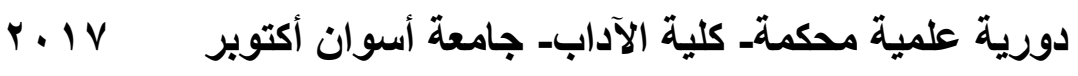

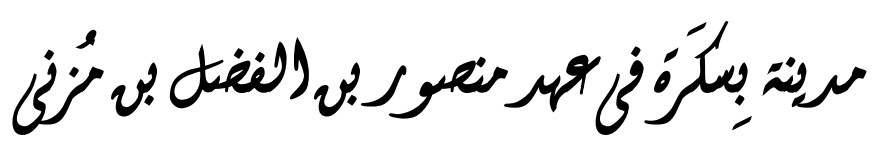

(irto-itas/orto-7at)

8) ()

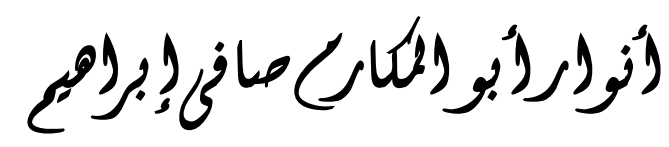

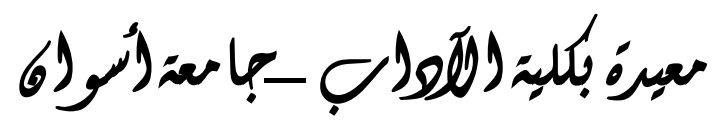

Y৭7 


\section{أولاً:-موقع مدبينة بسكرة}

اختلف المؤرخون حول التسمية الأصلية لمدينة بسكرة وكذلك الرحَّلة و الجغر افيين العرب والأوروبيون، وذلك لاختلاف المصادر التى نتطرف الى هذه المسألة التاريخية: - nمغن

فمنهم من يرى أن مدينة بسكرة مدينة بربرية قبل الميلاد بـ...باسنة

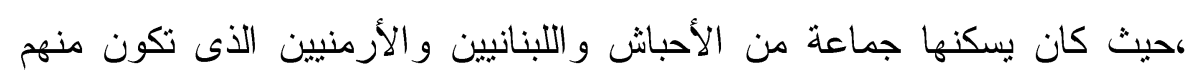
الشعب النوميدى'، وبعد حاكمها جرباص انتقل الحُكم من يده إلى القرطاجنيين

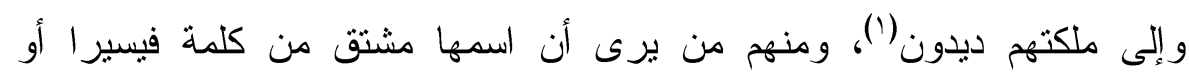

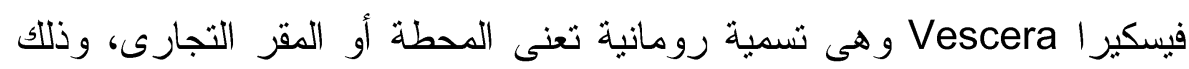
لموقعها الاستراتيجي المميز الذى جعلها منطقة عبور و التقاء بين الثمال و الجنوب، وكان من أهم ثلك المحطات الأساسية محطة خط اللميس الذى بناه

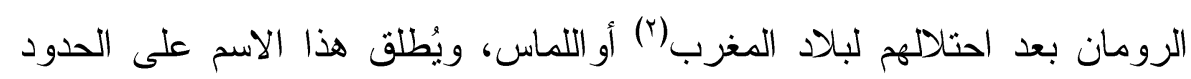

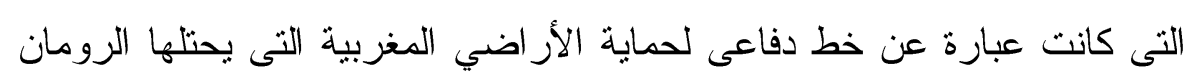
من هجمات القبائل البربرية(").

وفى القرن الثالث الميلادى انتشرت فى مدينة بسكرة العديد من الكنائس

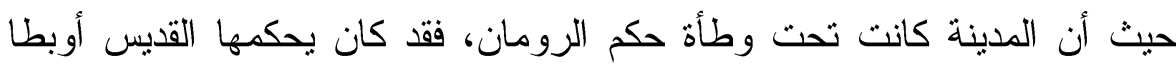

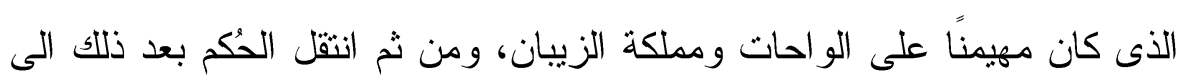
القديس فيليكس، حيث قام البابا بإبعاد القديس أوبطا عن الحُكم وقام بنفيه، و استمرت بسكرة تحت سيطرة رجال الدين المسيحي فترة من الزمن(؛)، وخلال

(1) أحمد خمار : تحفة الخليل فى نبذة من تاريخ بسكرة النخيل، دار الهذى، عين مليلة، الجزائر، r ו. זم، ص0.

(Y) فوزي مصمودى: بسكرة عروس الزيبان وبو ابة الصحر اء، بسكرة، الجز ائر، مجلة الفيصل،

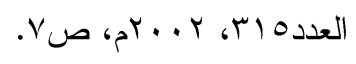

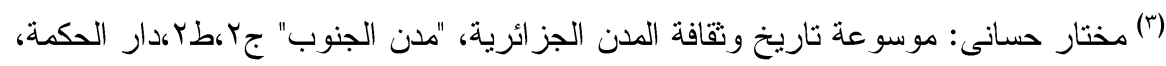

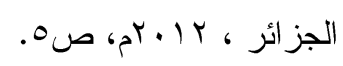

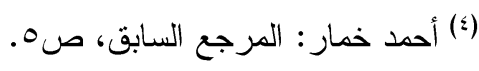


ازدهار الديانة المسيحية فى شمال إفريقيا كانت مركز أسققية نوميدية، حيث ذكر

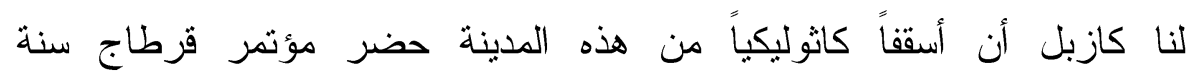

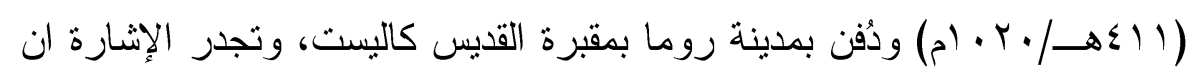

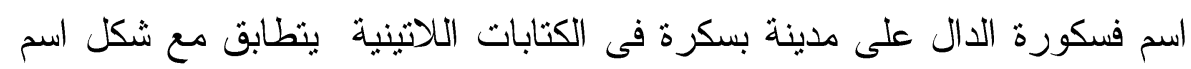

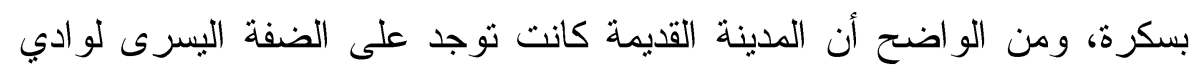
بسكرة يسار الطريق المتجه نحو سيدى عقبة، وفى هذا المكان تمت الاكتشافات الدالة على نلك المدينة (1).

ويرى البعض الآخر أن أصل تسمية بسكرة بهذا الاسم مشتق من سكرة،

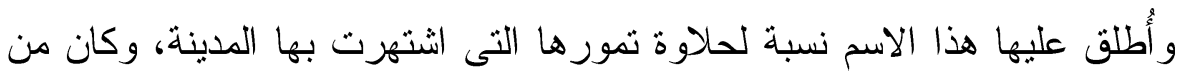

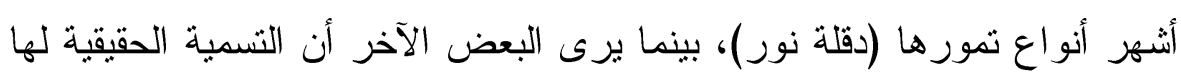

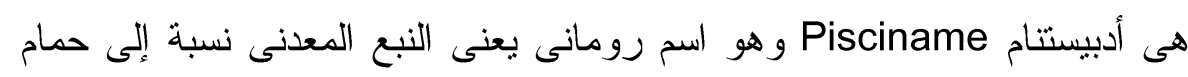

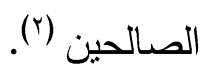

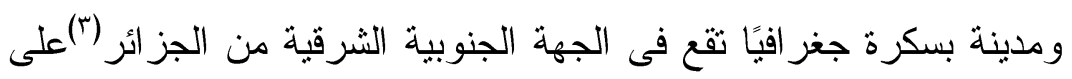

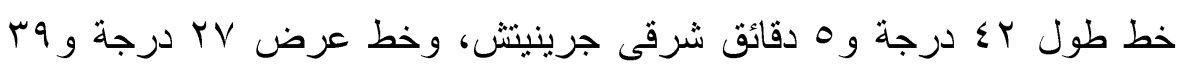

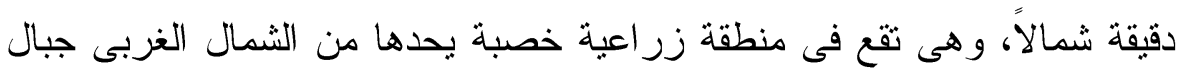

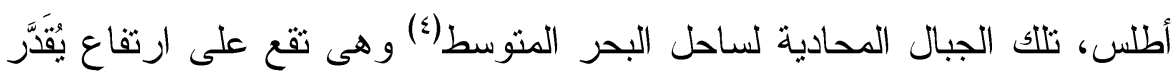

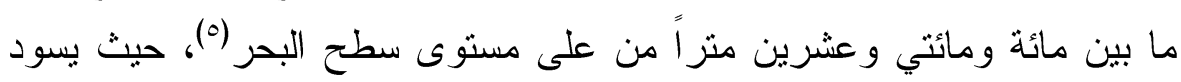

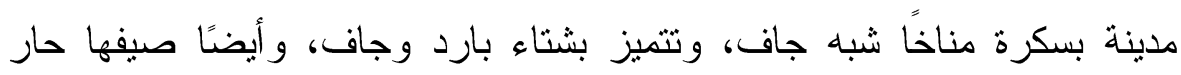
وجاف.

(1) مختار حسانى: موسو عة تاريخ وثقافة المدن الجزائرية، صجا.

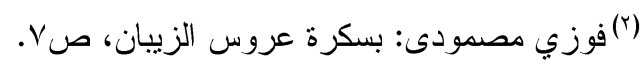

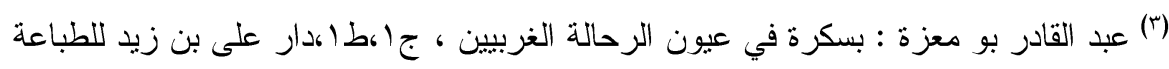

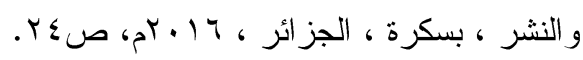

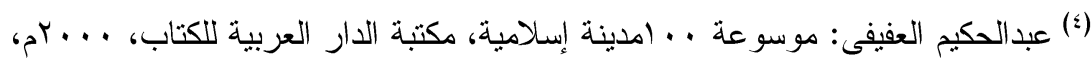
صrו". (0) (مختار حسانى، المرجع السابق، صه. 
أما بالنسبة لتساقط الأمطار فهى ضعيفة على مدار السنة، عدا فصل

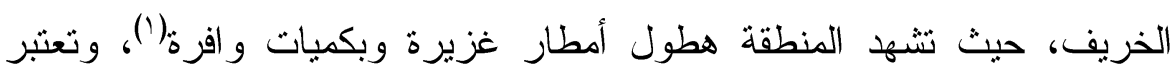

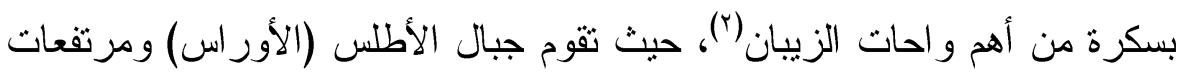

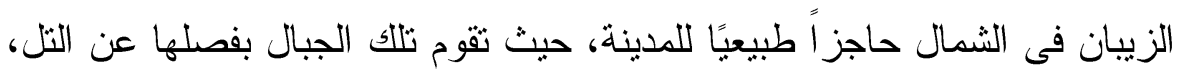

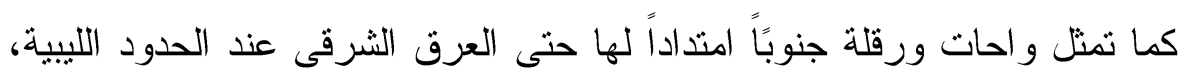
كما تقسمها شطوط "ملغيغ" إلى قسمين: القسم الثمالى: ويشمل المرتفعات السهبية

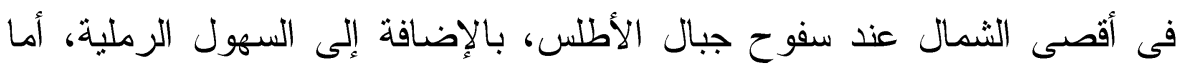
القسم الجنوبى للمدينة فتغطيه الكسبان الرملية(ऍ). و عَرَّن لنا ابن خلدون مدينة بسكرة "بأنها قاعدة وطن الز اب، وهى و احة

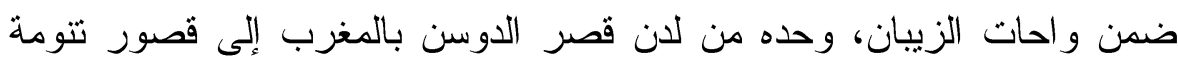

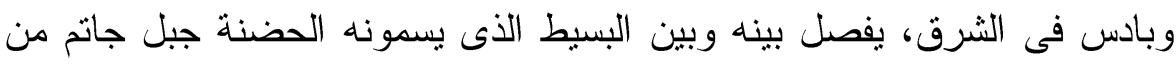

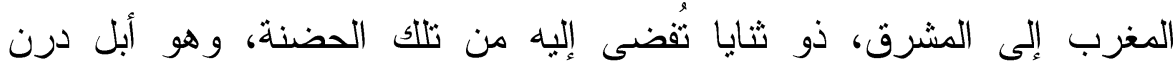

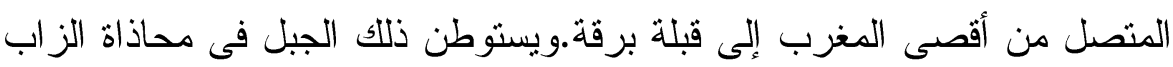

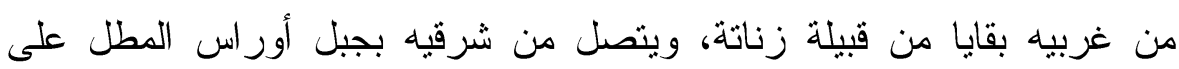

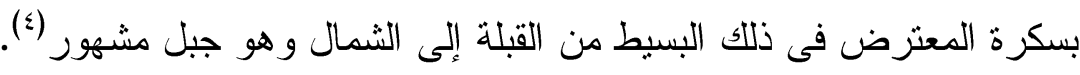
كانت هنالك الكثير من التعريفات حول مدينة بسكرة، حيث عَرَّنَ الحموي بسكرة "بكسر الكاف، وباء: وبأنها بلدة بالمغرب من نواحى الزاب، بينها وبين (") بسكرة أسو ار من حضارة: الجزائر، وزارة التقافة، صץ ا. (r) إسماعيل العربى: الصحر اء الكبرى وشو اطئها، المؤسسة الوطنية للكتاب، الجزائر،

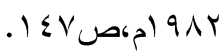

(") عبدالحميد بور ايوبن الطاهر: القصص الثعبى في مدينة بسكرة (دراسة ميدانية) المؤسسة الوطنية للكتاب، الجزائر، 919 (م، صوبن 9.

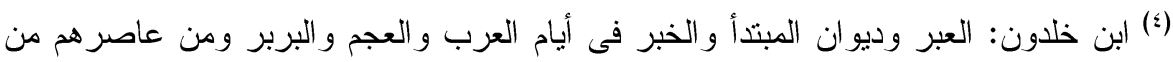

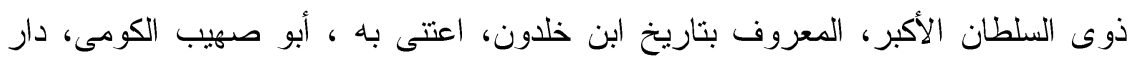

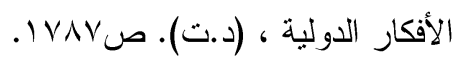


قلعة بنى حماد مرحلتان، وحيث يوجد بها العديد من النخل و السجر و القصب

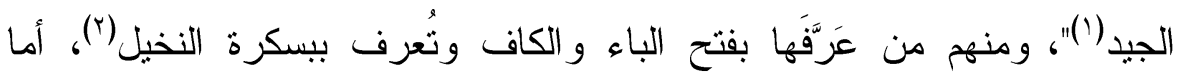

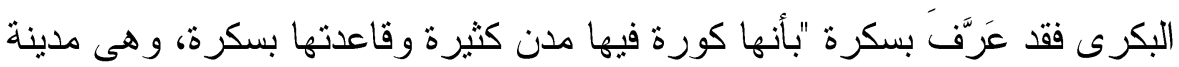

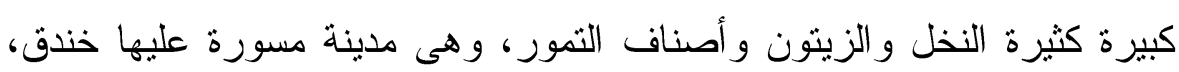

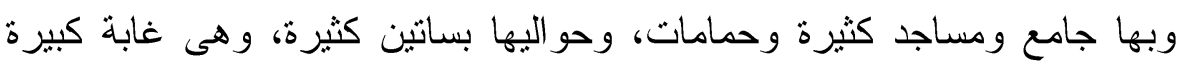
مقدار ستة أمبال فيها أجناس من التمور، وحول بسكرة أرباض خارجة ونا عن وهن

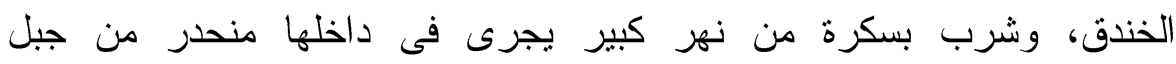

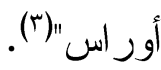

وقد كانت مدينة بسكرة غنية بالموارد المعدنية التى جعلتها سبيًا من أسباب العمران و العيش فيها، وكذلك جعلتها محط أنظار المؤرخين و الجغر افيين

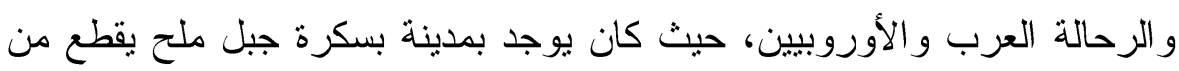

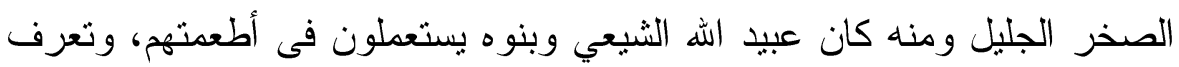
بيسكرة النخيل حيث قال فيها أحمد بن محمد المروذى الجيل

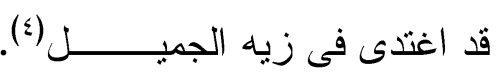
ثم أتى ببسكرة النخيل وذكر لنا ابن سباهى زاده أن بسكرة بكسر الباء الموحدة وقيل فتحها وسكون

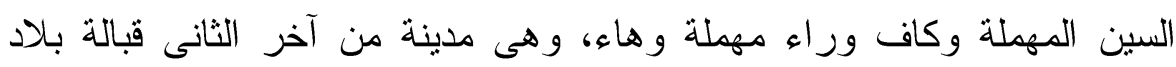
الغرب الأوسط، ومن بسكرة كان يُجلب التمر الطيب الى تونس وبجاية(ه)، بينما ولهاء

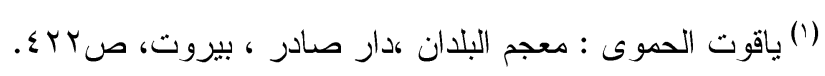

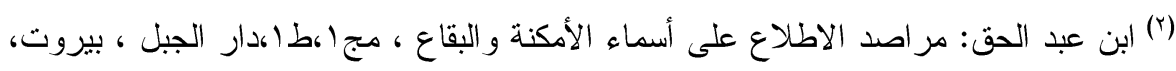

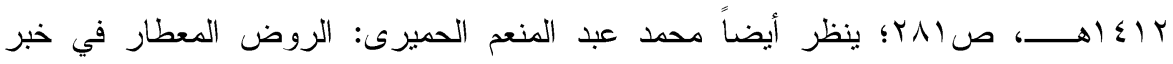

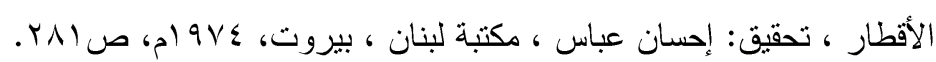

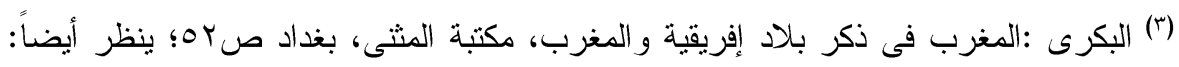

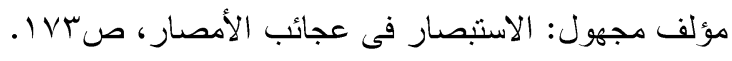

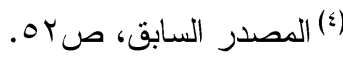

(o) ابن سباهى زادة : أوضح المسالك فى معرفة البلدان والممالك، تحقيق: المهدى عيد

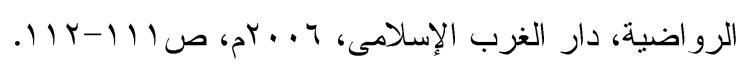


عرفها لنا صاحب الاستبصار بأن بسكرة مدينة كبيرة وبها العدبد من الحصون و القرى العامرة وهى قاعدتها(').

فى حين أخبرنا الوزان "بأن بسكرة مدينة تأسست على أنقاض المدينة

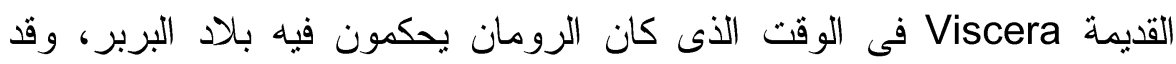

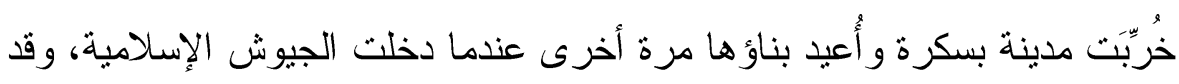

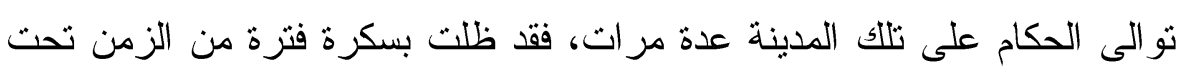

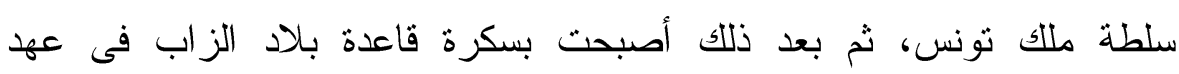
الحفصبين (ץ)

وقال عنها (ماركو يوداميريك وهيرنز) "بأنها بلد فريد غنى ذو إمكانيات

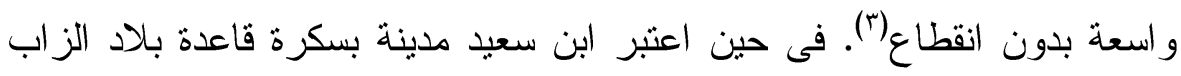

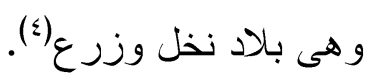

ووصفها لنا الورثنالنى " بأنها مدينة كثيرة المياه بين خلال البيوت فكل باب عند ساقية من الماء، ونخلها عظيم وزرعها كثثر، و هذه المدينة كانت فارهة

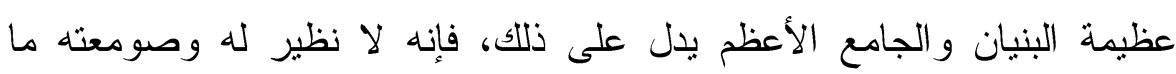
أحسنها وما أعظمها" (0.)

$$
\text { (1) مؤلف مجهول: الاستبصار فى عجائب الأمصار ، صسVI. }
$$

(Y) الحسن الوزان: وصف إفريقيا، ترجمة من الفرنسية : محمد حجى، محمد الأخضر،طب،دار

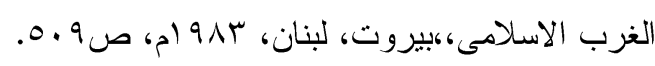
(") عبدالحليم صيد: أبحاث فى تاريخ زيبان بسكرة، مطبعة سوف، ص9؟r (2)ابن سعيد المغربى :كتاب الجغر افيا، حققه: إسماعيل العربى، المكتب التجارى للطباعة و النشر

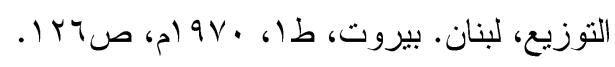

(0) الورثيلاني :الرحلة الورثيلانية المسماة نزهة الأنظار في فضل علم التاريخ و الأخبار، مطبعة

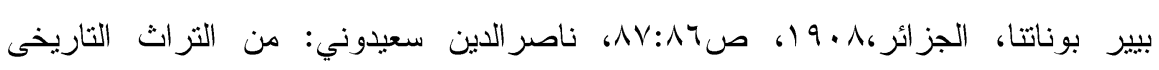

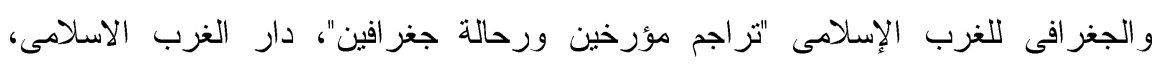

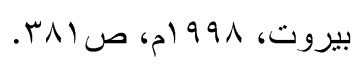


كما عرفها المدنى فى كتابه قائلاً: "بأن بسكرة كانت قرية بربرية عتيقة،

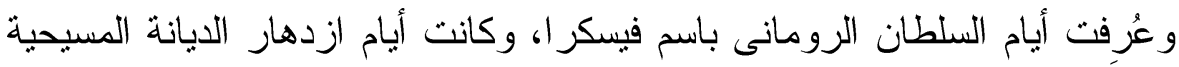
بالبلاد مركز أسققية، احتلها العرب تحت قيادة عقبة بن نافع، واستشهر عقبة بهابة و أصحابه بالقرب منها، وبعدها دخلت بسكرة تحت الحكم الأغلبى، ثم دخلت فى نى سلطة بنى حماد، وأخيراً استولى عليها الهلاليون وجعلو ها من أكبر مر اكزهم" (1). ويتضح لنا من ذلك مدى أهمية مدينة بسكرة ومكانتها فى إقليم الزاب، ويرجع ذلك إلى موقعها المميز، حيث أنها كانت محط أنظار الدول واتخاذها بهاه

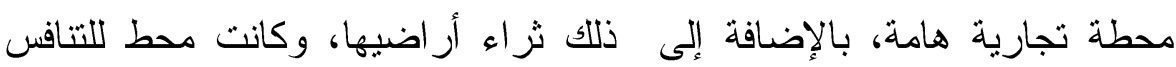

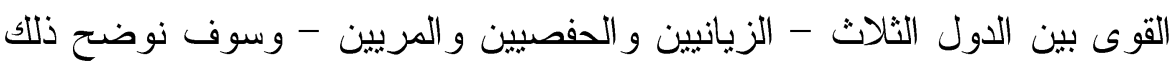
من خلال الدراسة.

\section{ثانيًا:-قري مدينة بسكرة: - مئة}

شملت مدينة بسكرة على العديد من المدن و القرى الهامة التى كان لها دور

كبير فى تاريخ بسكرة على مر العصور ، وكانت تمثناز تلك القري ببساطنها وكثرة

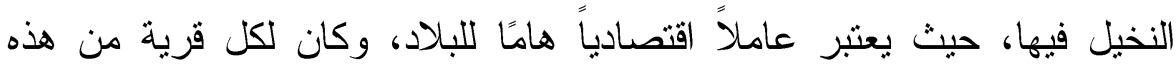

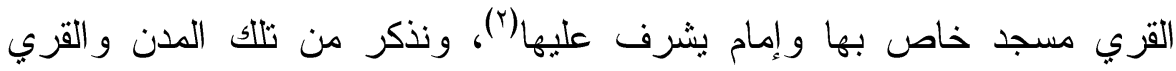
جمونة وطولقة ومليلة وملشون وبنطيوس وحياس وسوف نذكر كل نلاك المدن و القرى بشئ من التفصيل:

\section{1 - مدينة طولقة:}

مدينة بالمغرب من ناحية الزاب الكبير من صقع الحديد، حيث يُنسب إليها

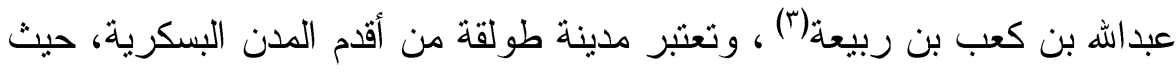

(1)

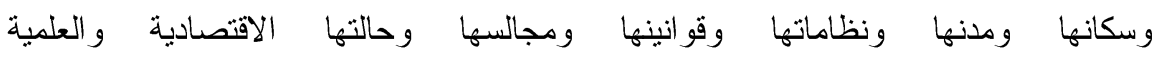

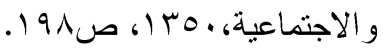

(ץ) أحمد خمار : تحفة الخليل في نبذة من تاريخ بسكرة النخيل، صب ا. (") (") ياقوت الحموي: معجم البلدان، مجع، ص.0. 
تعود جذور تلك المدينة إلى عهد القرطاجيين، حيث كانت تلك المدينة بربرية، وكانت ثربطها علاقات وُدِّ بينها وبين القرطاجيين، ويرجع سبب تسمينها بهذا

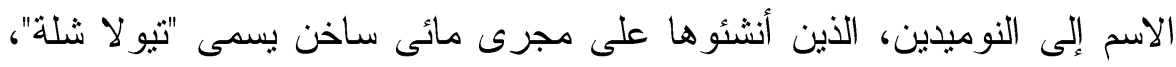

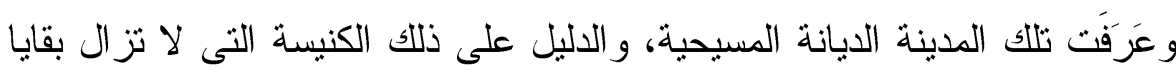
آثار ها إلى يومنا هذا. و افتتحها القائد عقبة بن نافع، وبنى فيها مسجداً صلى فيه ثلاث جمعات،

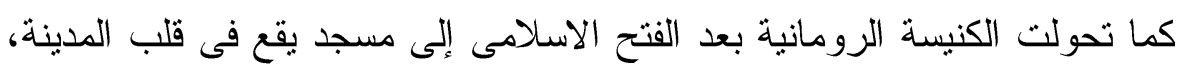

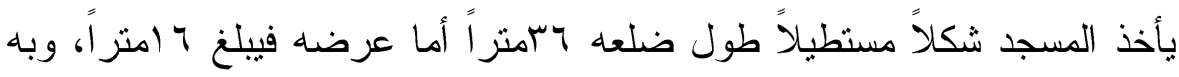
أربع واجهات: الو اجهة الرئيسة بها بابان ونافذتان، الواجهة الثانية بها باب يطل

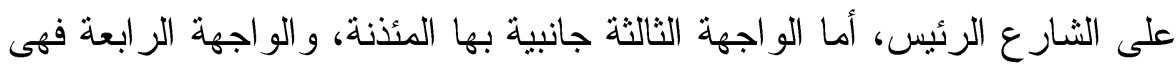

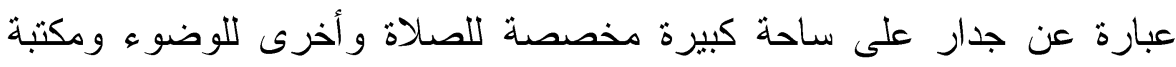
وساحة صغيرة، وتعتبر مئنة المسجد العتيق من المآذن ذات القاعدة المربعة، يبلغ

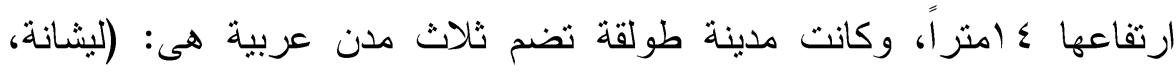

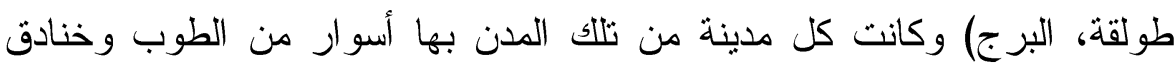

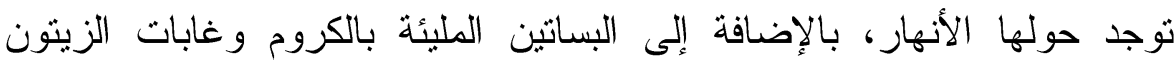

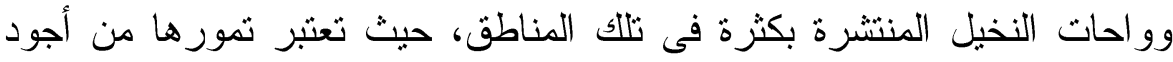

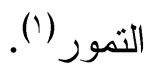

\section{r - مدينة مليلة:}

بالفتح ثم الكسر، وباء تحتها نقطتان، و لام أخرى، وهى مدينة بالمغرب

بالقرب من سبتة على ساحل البحر (r).

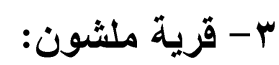

من قري بسكرة من ناحية إفريقية القصوي، يُنسب إليها أبو عبدالملك

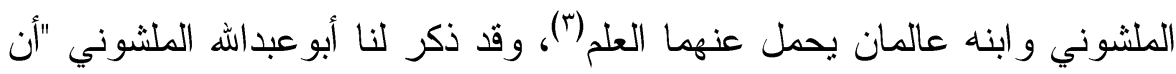

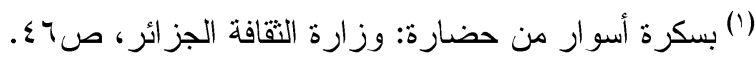

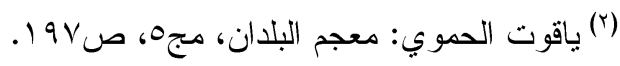

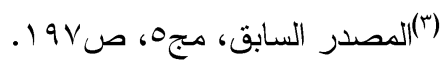


في طريق بسكرة يوجد جبل" فيه كهف يوجد به رجل قتيل لم يعرف أحد من أى

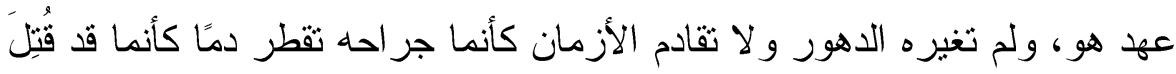

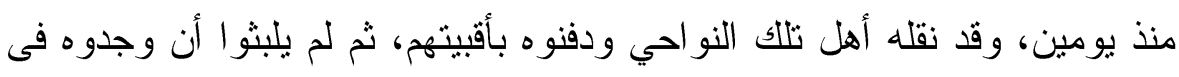
الكهف على حاله، ويقال إنه من الحواريين، كما ذكر محمد بن يوسف أن هذا القتيل فى شق جبل بشرقي عين، ورذه العين عظيمة بين مرماجنة وبين مدينة

سبيية (1)

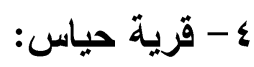

هي القرية الثى نزل بها العرب فى القرن الخامس الهجري(؟).

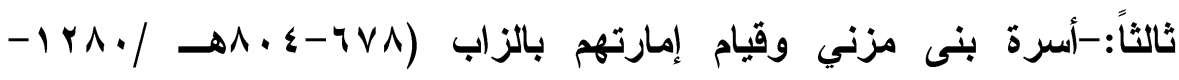
$:(\rho) \varepsilon \cdot r$

يرجع أصل بنى مزنى إلى إفريقية وأنهم من العرب، حيث أنهم وصلوا

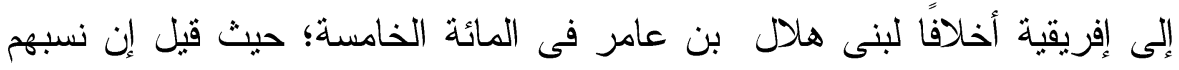

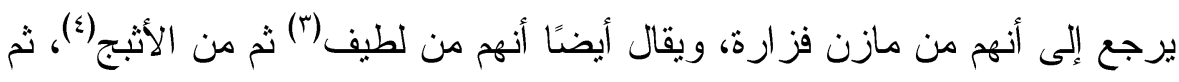
(1) محمد عبدالمنعم الحميري: الروض المعطار فى خبر الأقطار ، صع الإ؛ مؤلف مجهول:

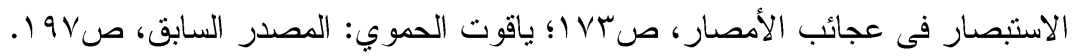

(ץ) أحمد خمار : تحفة الخليل في نبذة من تاريخ بسكرة النخيل، صب ا.

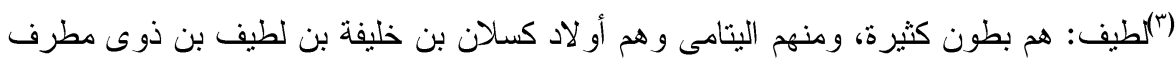

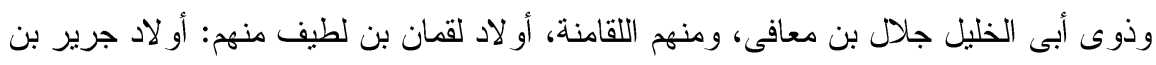

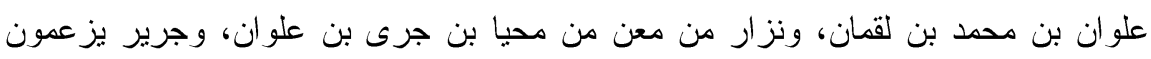

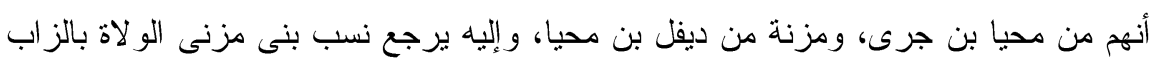

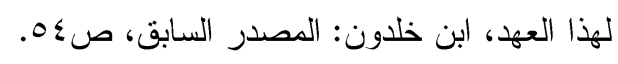

(2)الأثبج: هم من الهلالبين وكانوا أكثر عدداً وأوفر بطوناً، وكان منهم الضحاك وعياض ومقدم

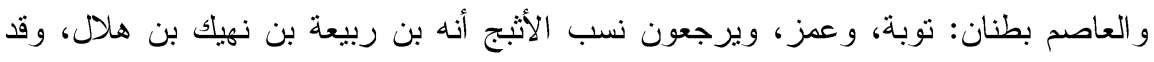

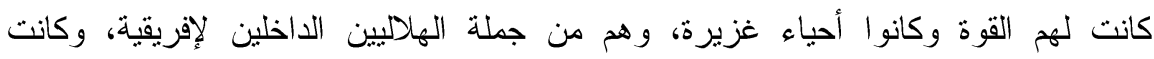

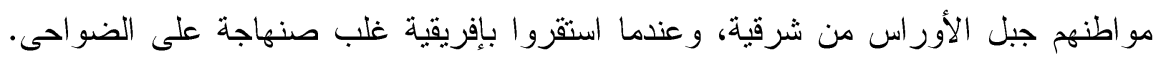
ابن خلدون: المصدر السابق، صرئ. 
من بنى جزى بن علوان بن محمد بن علوان بن خليفة بن لطيف(')، بينما ذكر لنا

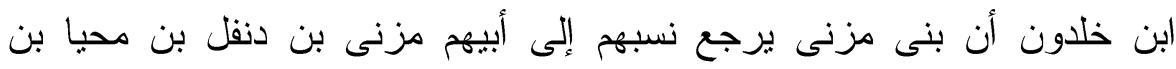

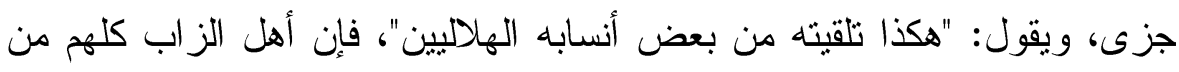

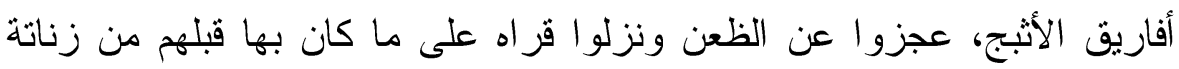

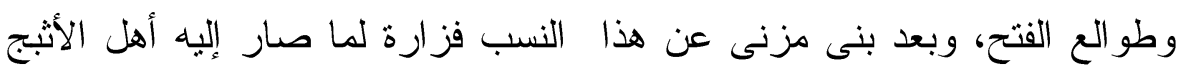

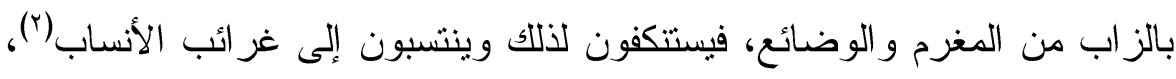

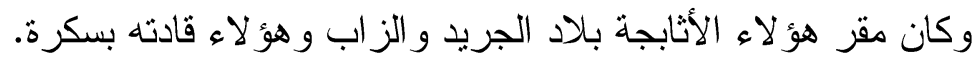

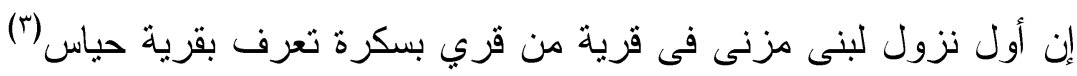

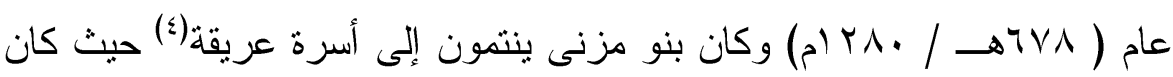

('المقريزي : درر العقود الفريدة فى نزاجم الأعيان المفيدة: مج)، حققه وعلق عليه: محمود

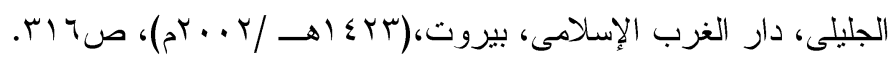

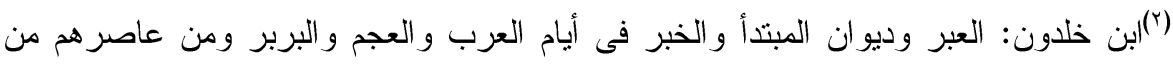

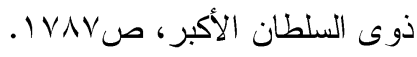

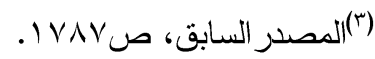

(؛)كان الفتح الإسلامى لبلاد المغرب بدأ بقيادة عمرو بن العاص و عقبة بن نافع، اتجهو ا إلى بلاد

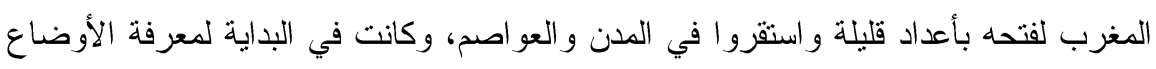

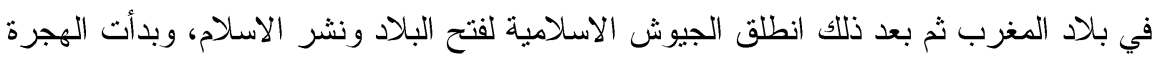

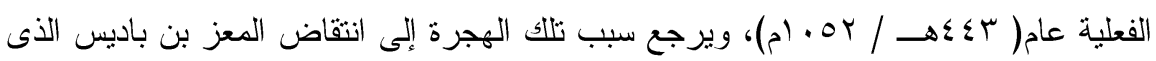

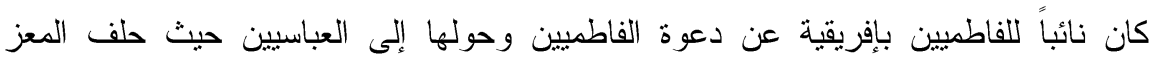

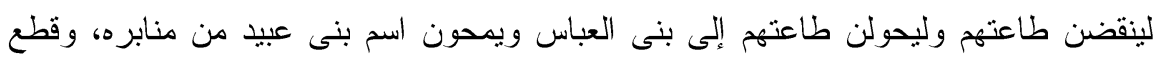

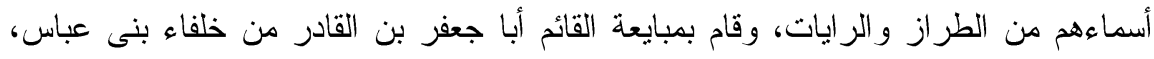

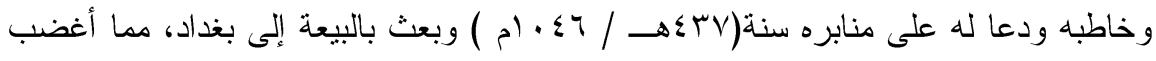
ذلك المستصر فأشار عليه وزيره أبومحمد الحسن بن على البازورى باصطناع العرب أحياء

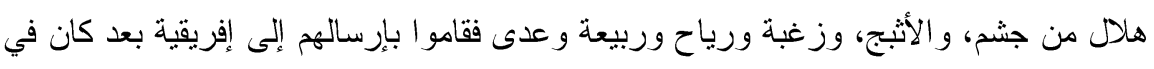
مصر وقال لهم" لقد أعطينكم المغرب، وملك المعز بن بلكين الصنهاجى العبد الأنيق فلا

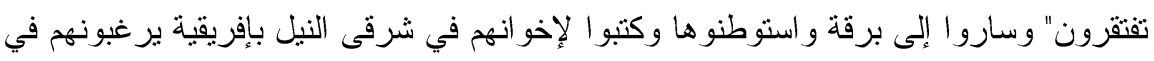

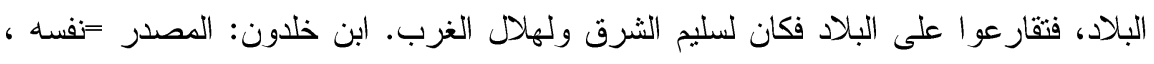
ص949، ـ107،107؛ جورج مارسيه: بلاد المغرب وعلاقاتها بالمشرق الاسلامى في

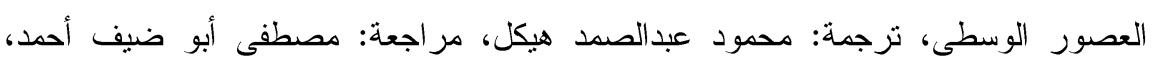


نزولهم فى القرن السابع الهجرى والثالث عشر الميلادى مع الدواودة(1)، فلما

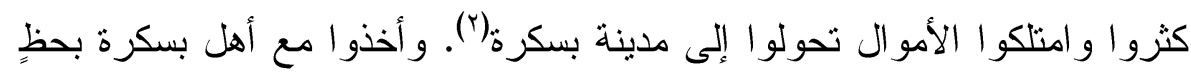

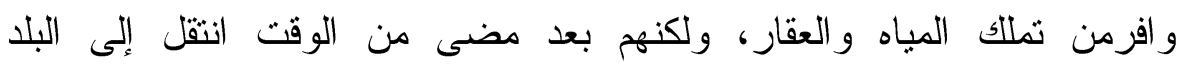

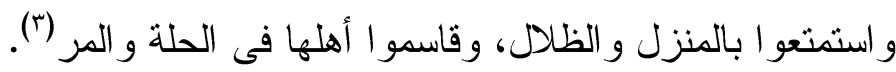

وفى بداية الأمر كانت إمارة الزاب إلى هذا العهد لبنى رمان(؛) البسكريين

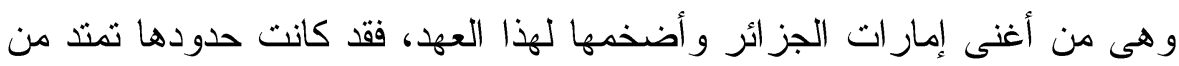

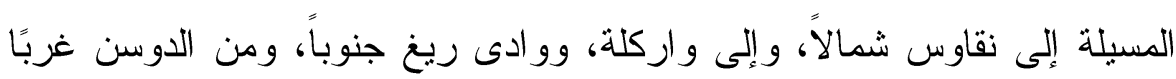

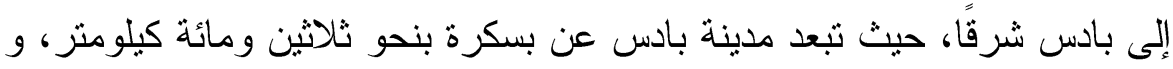
استمر بنى رمان على و لايتهم لبسكرة.

فقد كان النزاع بينهم وبين بنى مزنى عليها، فنزلوا حولها إلى عصر

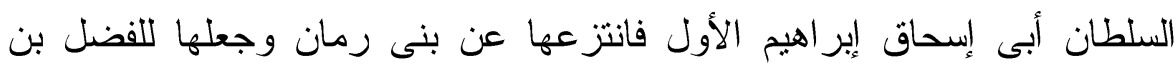

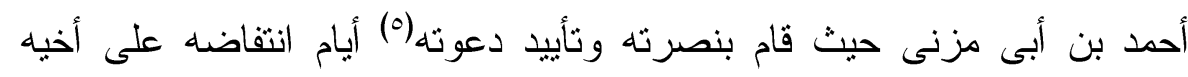

$=$

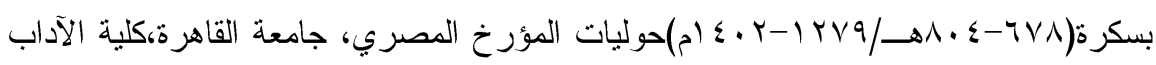

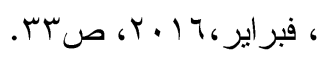

(')Marc cote: La ville et le desert Le Bas- Sahara Algerien, Paris, Page 221.

$$
\begin{aligned}
& \text { (†) المقريزي: درر العقود الفريدة فى تراجم الأعبان المفيدة، مج)، صها آ. }
\end{aligned}
$$

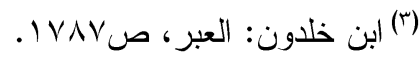

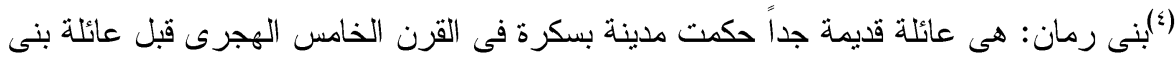

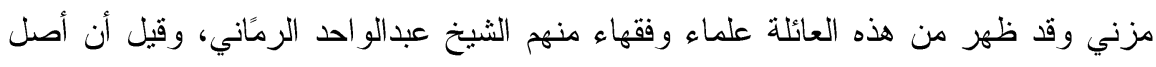

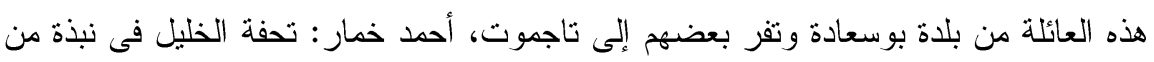

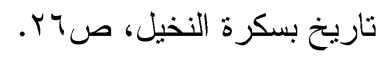
(0) 
المستتصر ، فشكر له السلطان موقفه هذا وو لاه إمارة الز اب اعنز افًا بمساعدته له

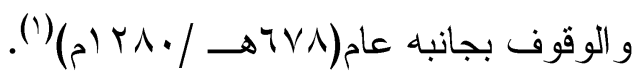

بعدما فر أبو إسحاق إبر اهيم من أخيه المستتصر وصل إلى تلمسان(؟) و التجأ إلى الأندلس، وظل أبو إسحاق هناك بنتظر الفرصة للعودة وظل هنالك حتى إنى

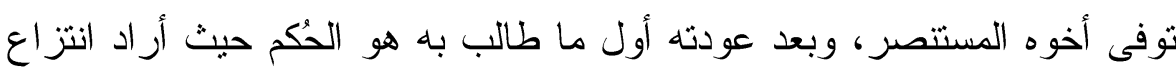

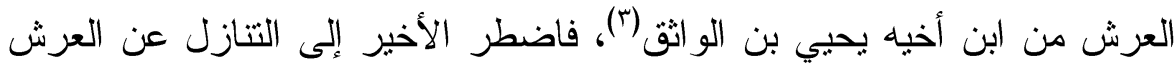

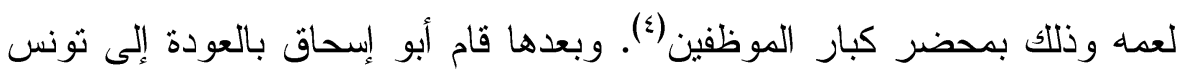

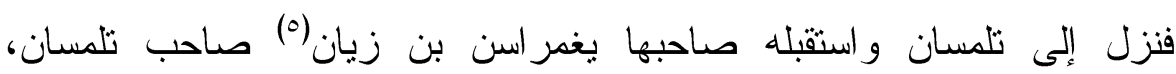

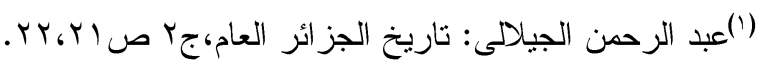

(Y)

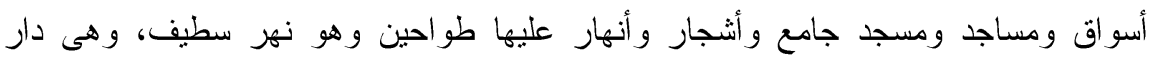

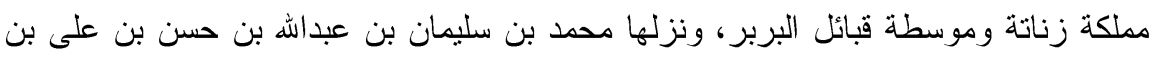

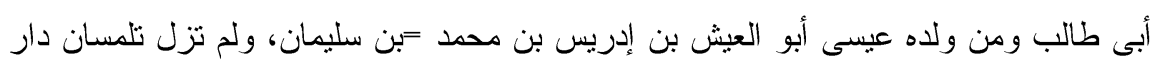

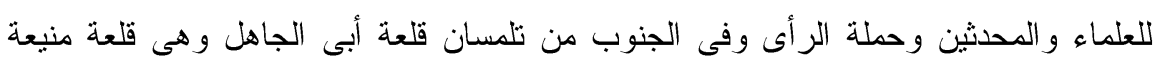

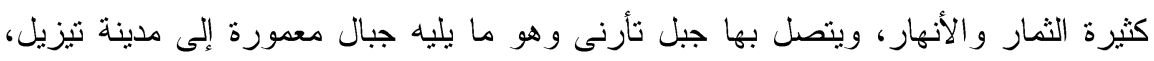

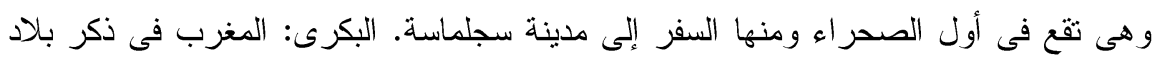

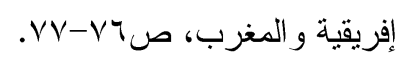

(5) (") المطوى: السلطنة الحفصية، صع بr.

$$
\text { () برنشفيك: تاريخ إفريقية فى العهد الحفصى، جا، صل ـ 1. }
$$

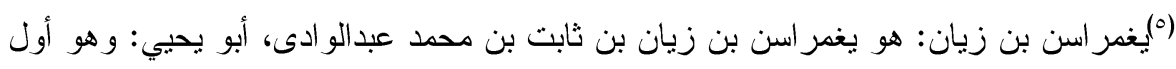

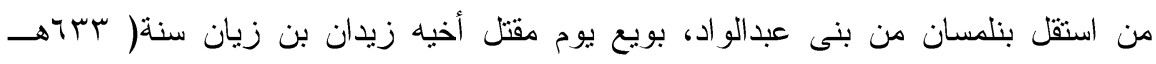

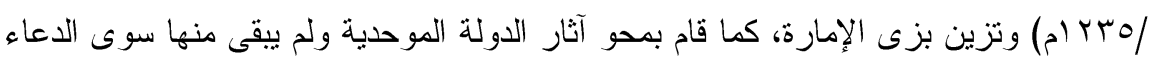

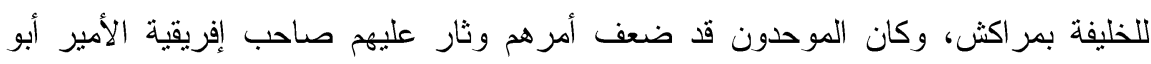

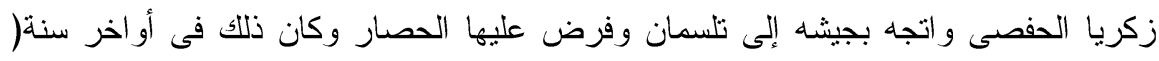

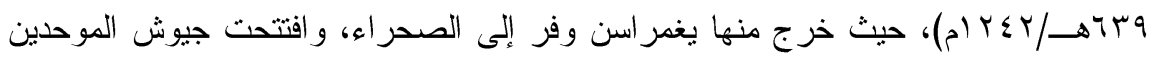

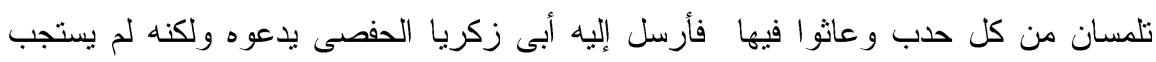

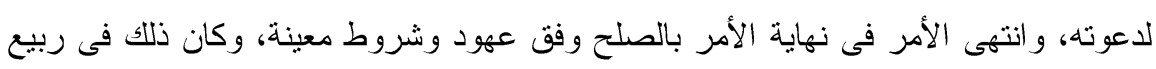


بالإضافة إلى ذلك كان أهل بجاية ناقمين على و الى الأشغال عندهم فقامو ا بقتله،

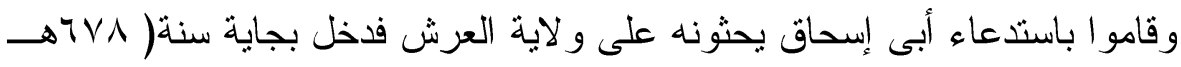

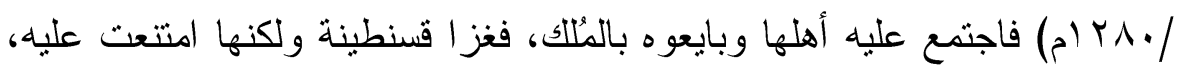

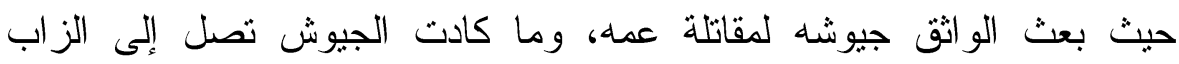
الجزائرى حتى تقدمث بنفسها إلى أبى إسحاق فبايعته بالمُلك وكتبت وثثيقة بذلك بعثت بها إلى الو اثق بتونس، فنتازل مكرهاً عن العرش وخلع نفسه، وبذلك كانت

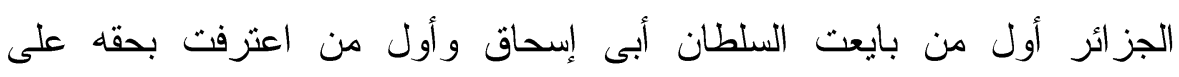
العرش (').

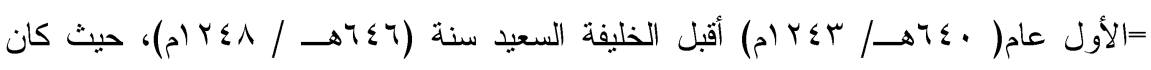

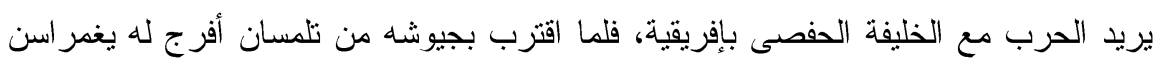

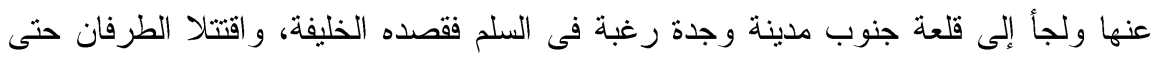

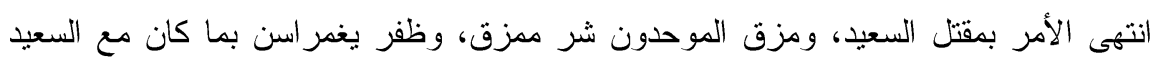

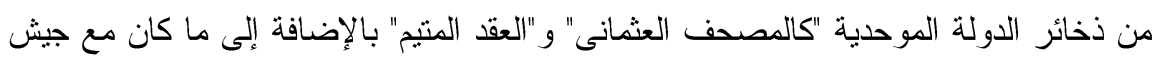

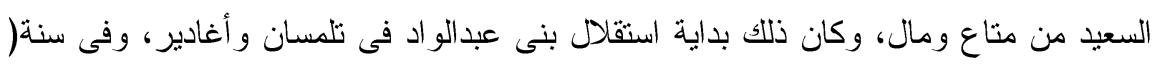

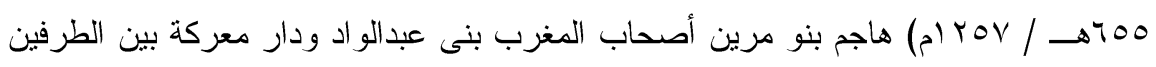

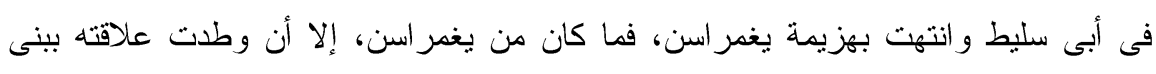

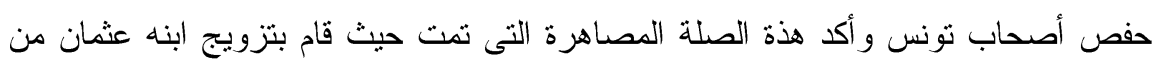

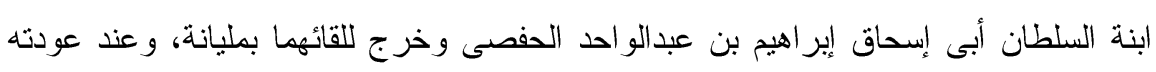

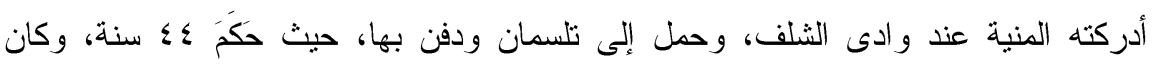

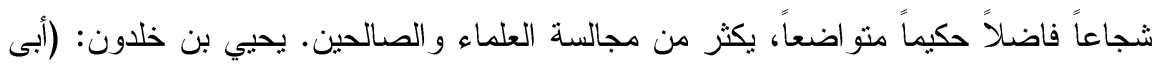

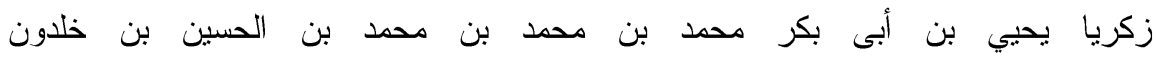

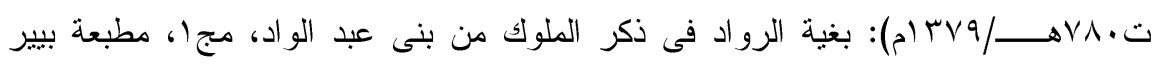

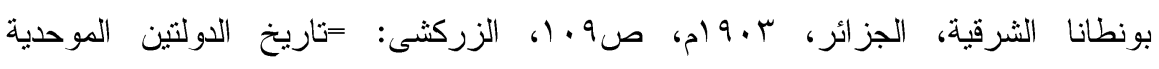

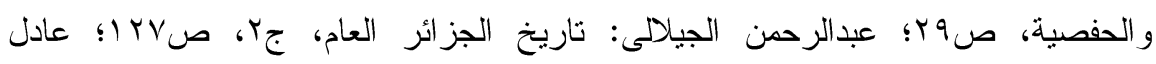

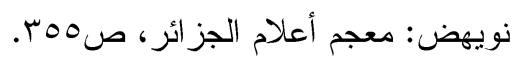

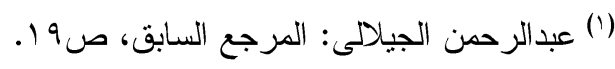


وبعد أن تولى أبو إسحاق مقاليد الحُكم بتونس، عقد للفضل على الزاب

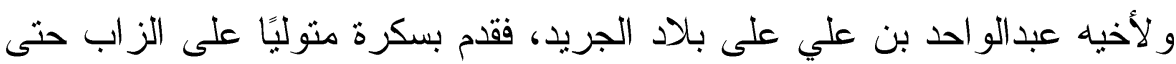

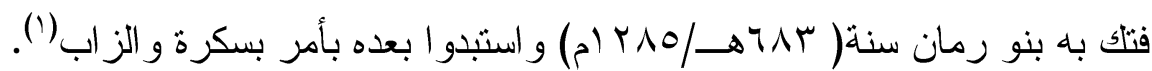
رابعًا: بسكرة فى عهد منصور بن الفضل بن مزنى (rq

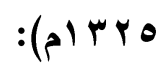

منصور بن الفضل بن على بن أحمد بن الحسن بن على بن مزني، هو

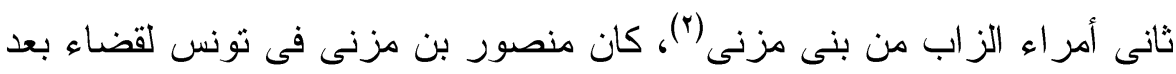

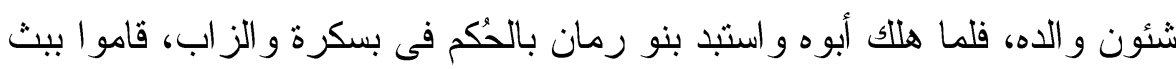

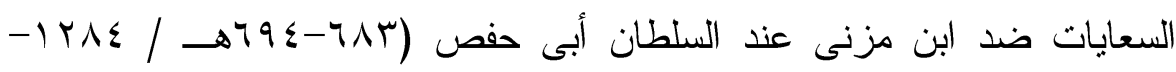

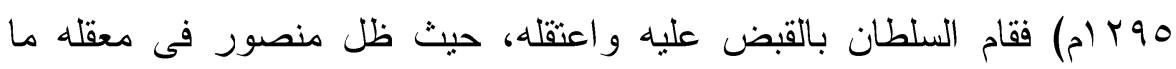
يقارب سبع سنوات(")، و أثناء تو اجد منصور فيى الاعتقال بتونس، استطاع الأمير

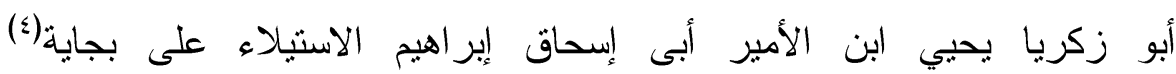

(') المقريزى: درر العقود الفريدة فى نر اجم الأعيان المفيدة، صح اس.

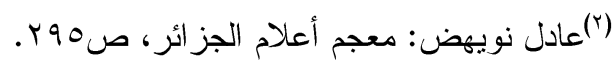

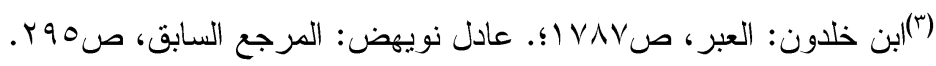

() بجاية: بالكسر وتخفيف الجيم،، و ألف، وياء، وهاء: وهى مدينة على ساحل البحر بين إفريقية

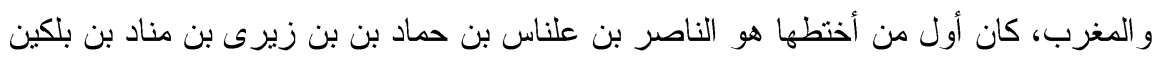

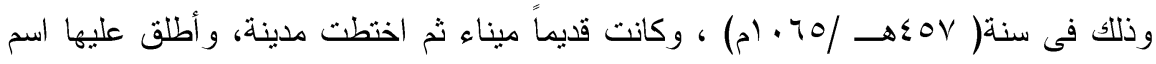
الناصرية ثم الى الناصر بن علناس الذى قام ببنائها، وكان سبب بناء تلك المدينة كما أخبرنا

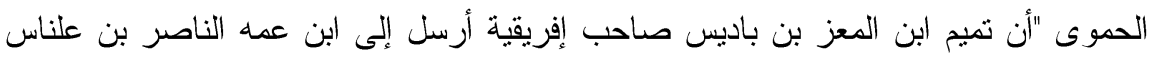

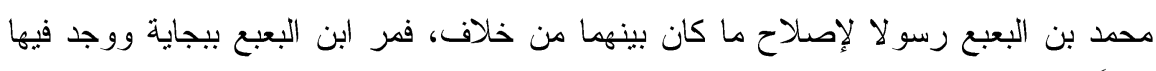

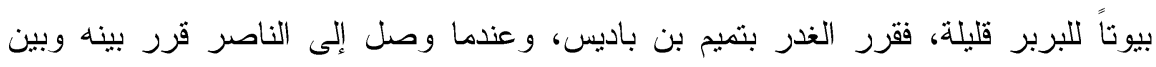

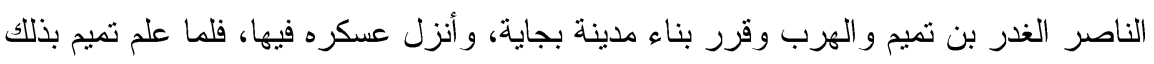
أرصد له العيون فقبض عليه وقم بقتله، وأخبرنا الإدريسى أن مدينة بجاية كان أهلها مياسير

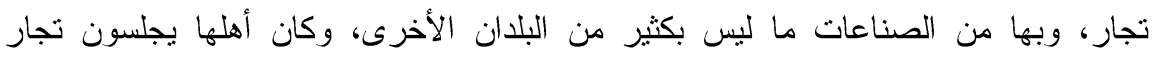

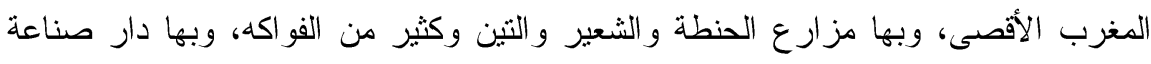

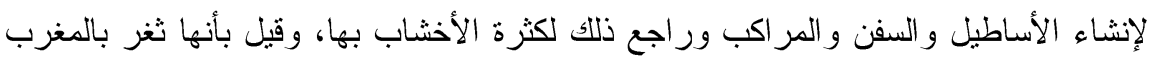
الأوسط على بحر الروم، عند مصب نهز مضاف إليها وهو ثغر "صلدا" القديم Saldae، 
وقسنطينة(1) وبونة(ץ) و انضمت إلبه الأعراب و أطاعته بجاية و الجزائر وبسكرة،

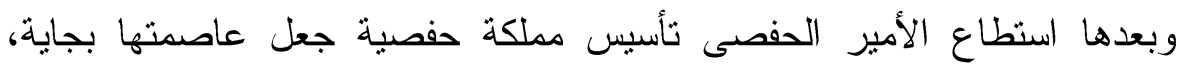
وبذلك انقسمت الدولة الحفصية إلى قسمين أولهما شرفى حيث ضم المير لمتلكات الأفريقية بالمغرب الأدنى "تونس"، وثانيهما قسم غربى ضم ممنلكات الدولة فى في الدئ

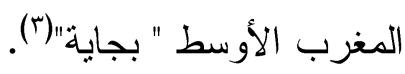

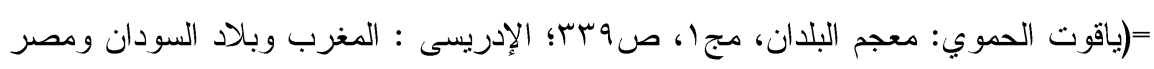

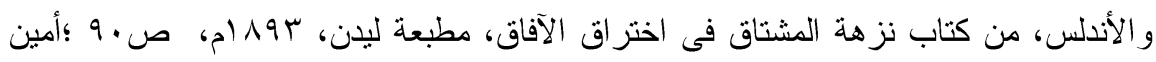

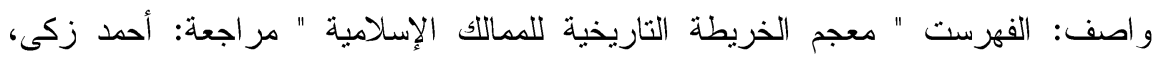

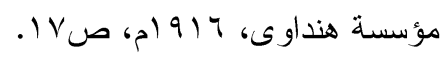

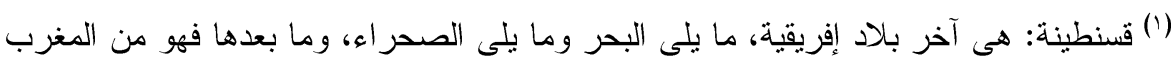

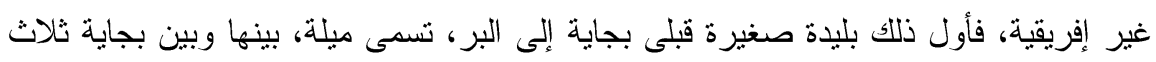

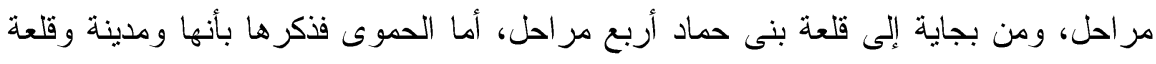

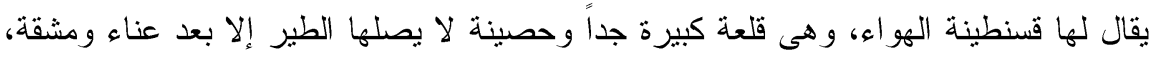

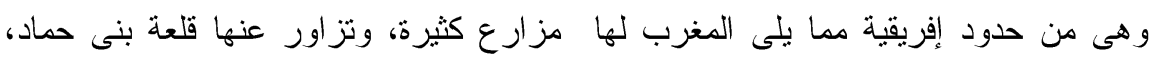

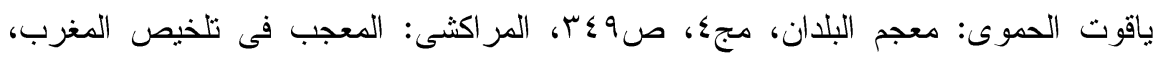

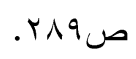

(r) بونة: مدينة بإفريقية بين مرسى الخرز وجزيرة بنى مزغناى، وهى مدينة حصينة مقتدرة

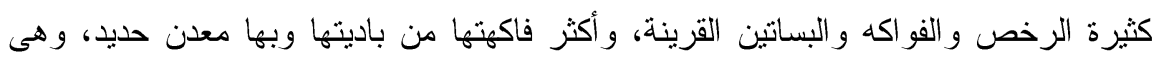

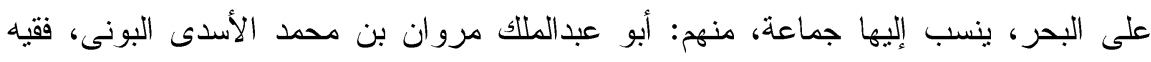

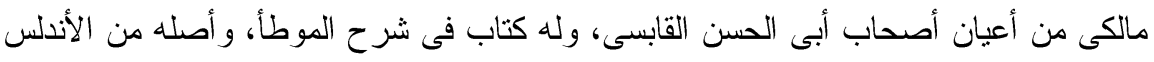

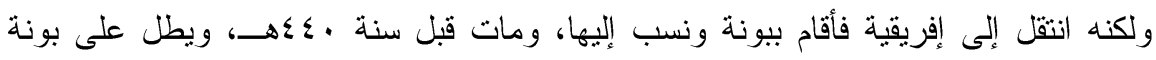

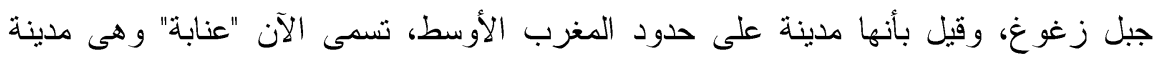
Hippos Regnis

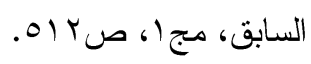

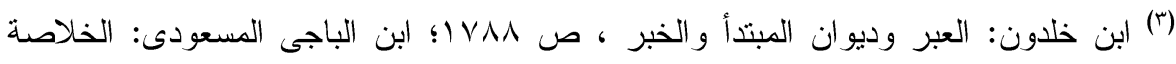

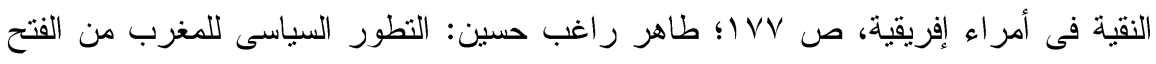

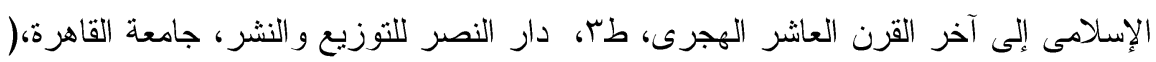

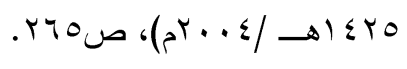


وخلال كل ثلك الاضطر ابات التى شهدتها الدولة الحفصية استطاع منصور بن مزنى الفرار من محبسه بتونس، ولحق بكرفة من أحياء هلال بن عامر، وهم

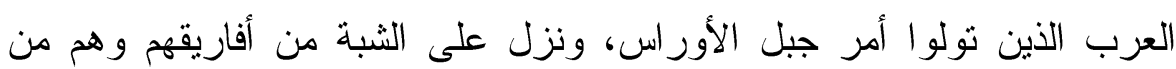

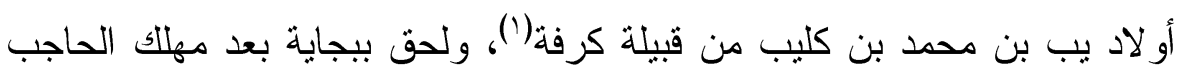

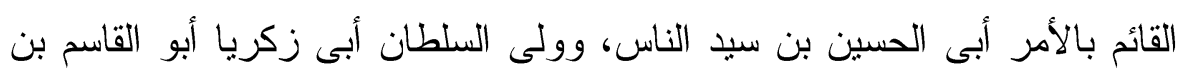

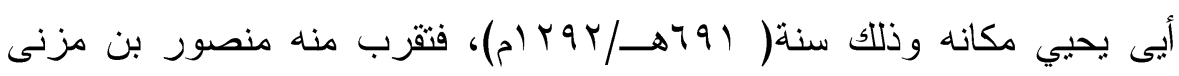
و لازم خدمنه، و أغدق عليه بالتحف وتعهد له بتحويل الدعوة إلى الزاب لسلطانه،

$$
\text { وتسريب الأمو ال و الجباية إليه( (r). }
$$

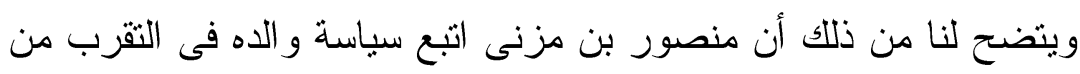

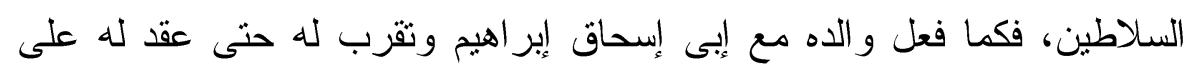
الزاب كذلك منصور بنى مزنى تقرب من أبى زكريا الحفصى حتى أولاه إمارة إنى إنى

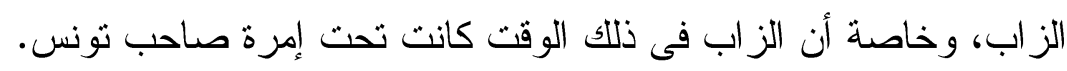
عقد الأمير أبى زكريا الحفصى لمنصور بن مزنى على الزاب التى كان

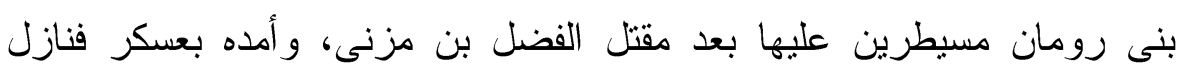

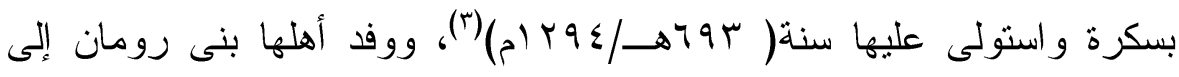

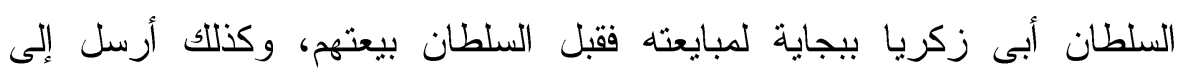

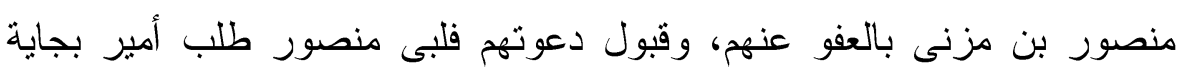

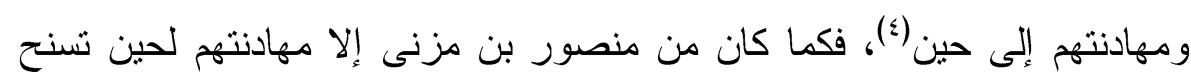
الفرصة للانتقام منهم لقتلهم أبيه.

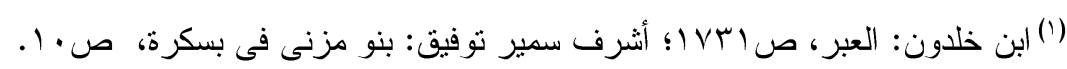

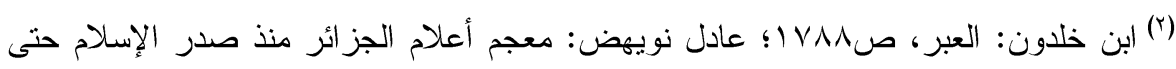

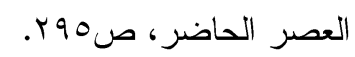

(") (") عادل نويهض: المرجع السابق، ص90r ب.

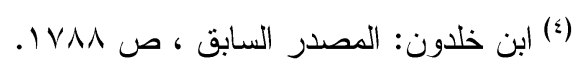


بدأ منصور بنى مزنى بتزسيخ أقدام إمارنه بإقليم الزاب، فقام ببناء قصرٍ

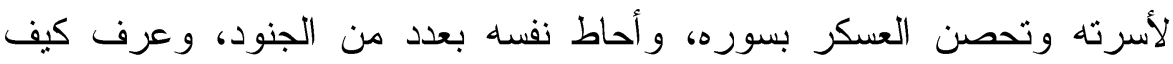

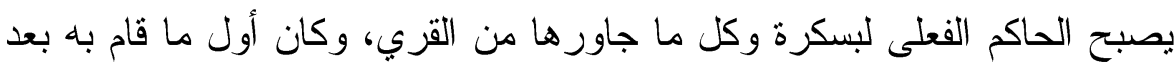

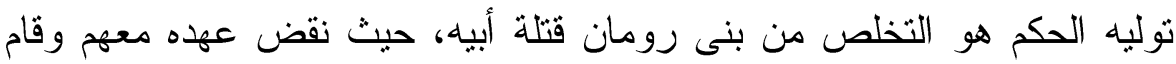

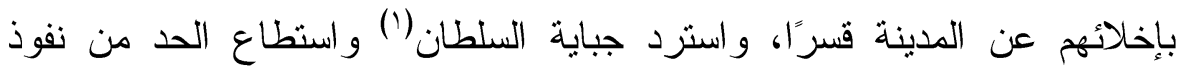

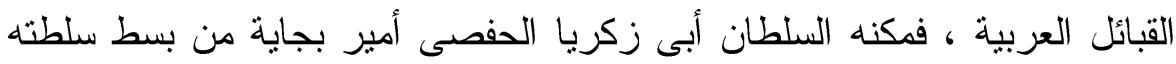

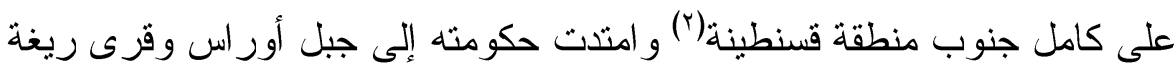

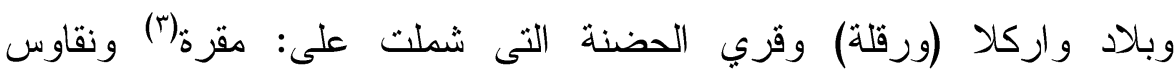

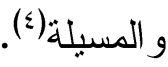

فقد استطاع منصور النقرب إلى السلطان و العمل على نوفيز أموال

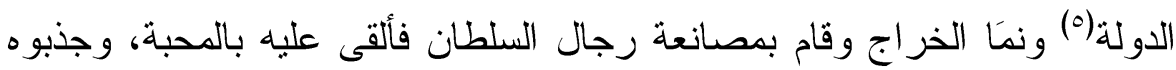

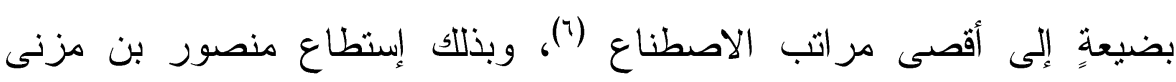

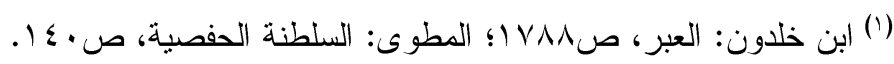

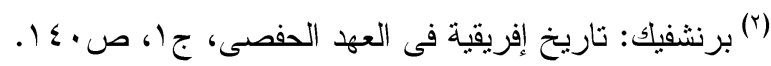

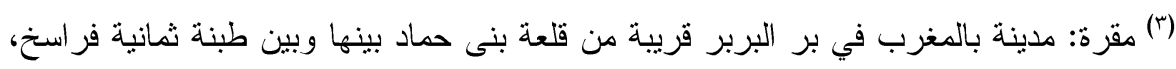

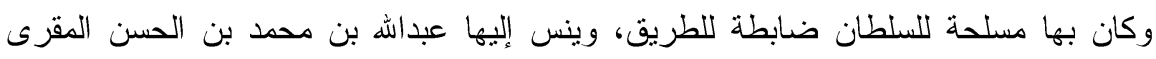

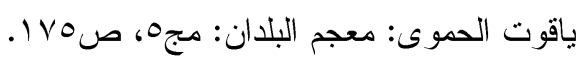

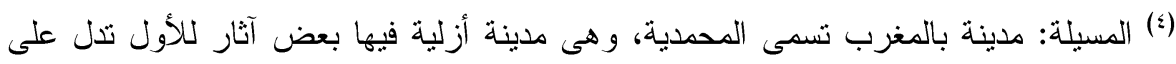

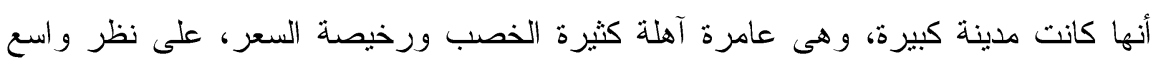

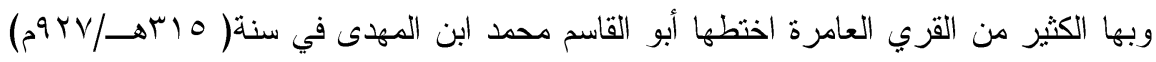
و أبو القاسم كان يلقب بالقائم بعد المهدى من المنتسبين إلى العلويين الذين كانو البمصر ، وينسب

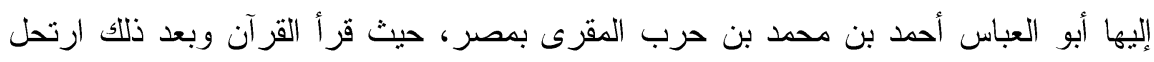

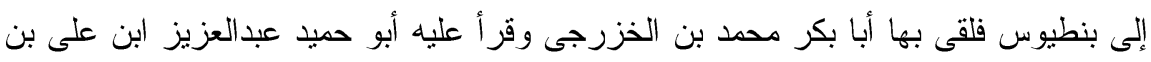

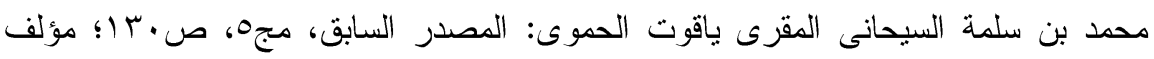

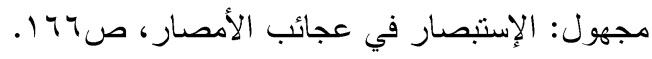

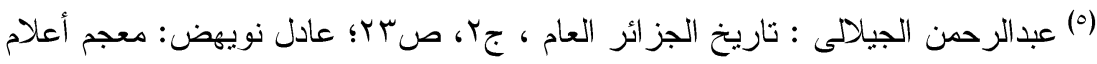

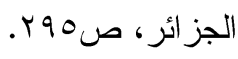

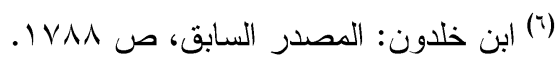


ترسيخ أقدام إمارته وبسط سلطته على إقليم الزاب، فقد اتسعت إمارة بنى مزنى

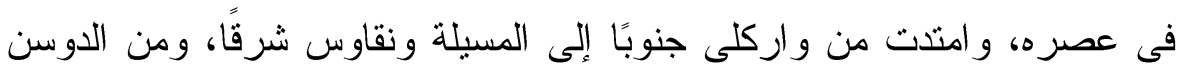
إلى بادس شرقًا، وفى السنة السابعة للهجرة توفى السلطان أبو زكريا وتولى الحكم ولى ونى

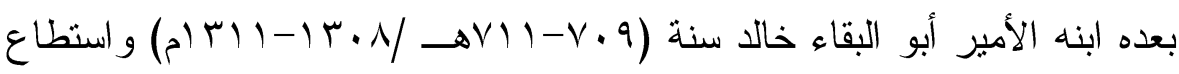
أن يستقل ببجاية ونونس، وتمكً من فرض الوحدة بين المملكتين الحفصينين بحد

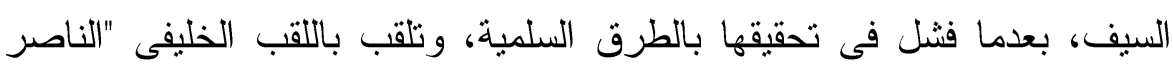

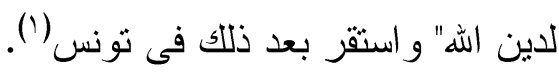
بعدما تولى أبو البقاء خالد حكم الدولة الحفصبة كان أول ما قام به أن

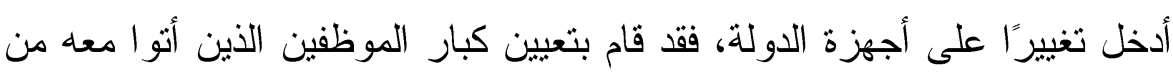

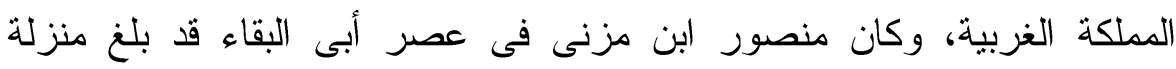

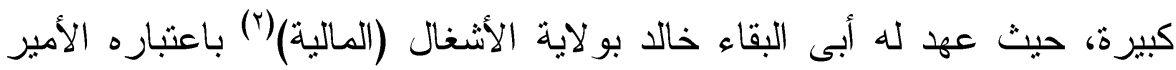

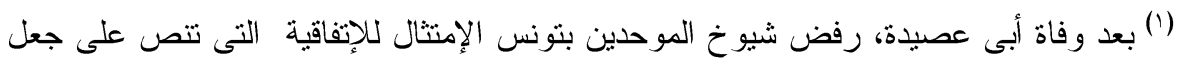

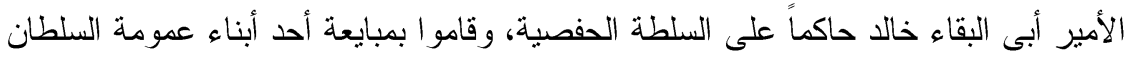

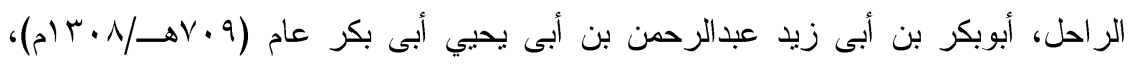

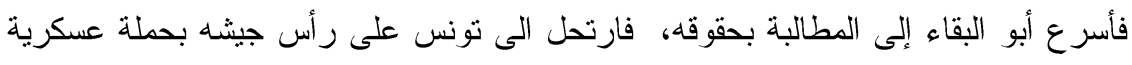

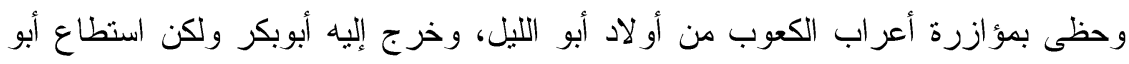

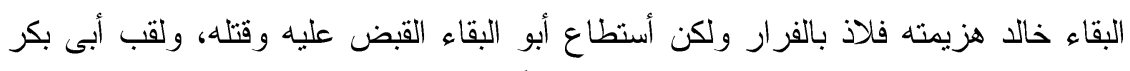

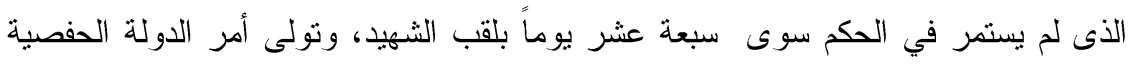

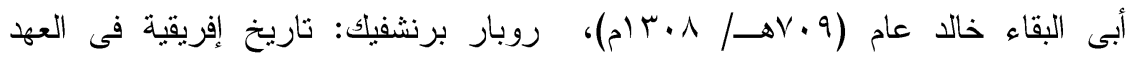

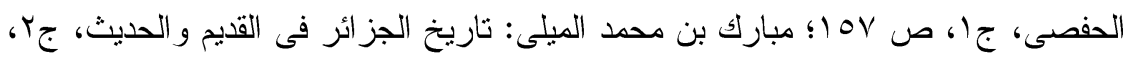
صדיז.

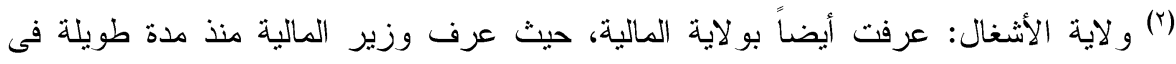

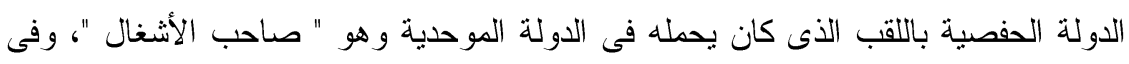

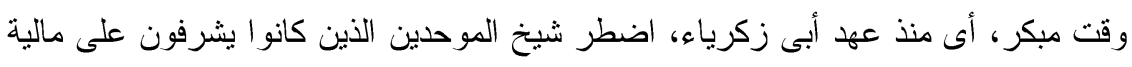

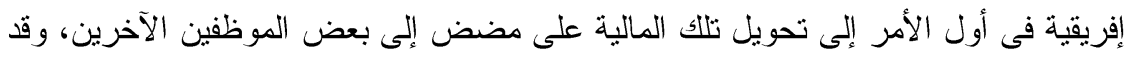

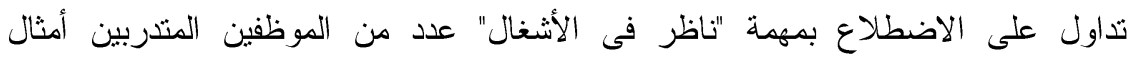

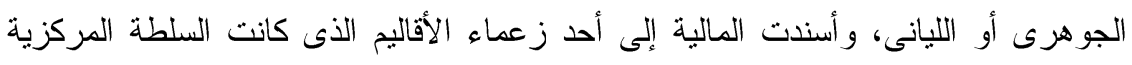

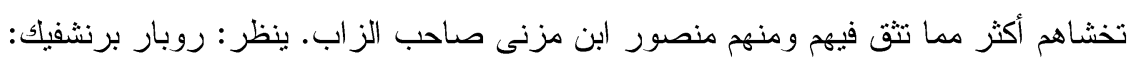


الأقوى نفوذًا فى الزاب(') وقويت علاقة منصور بحاجب أبى البقاء القائم بأمر

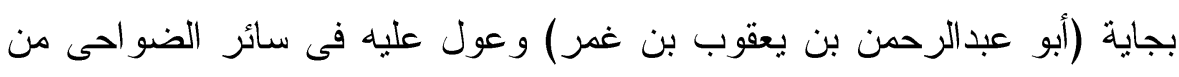

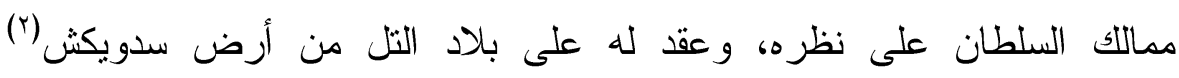
و عياض فاستضافها إلى عمله، وكان منصور ابن مزنى يتردد إلى بجاية لزيارة السلطان و المطالعة على أعماله (").

ويبدو أن ثلاك المكانة المميزة التى وصلها منصور بن مزنى عند السطان

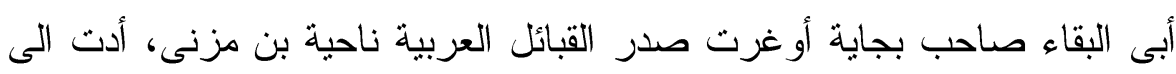
فكرة الانتقام والتخلص منه فانتهزوا فرصة عودته من سدويكث بعد زيارته

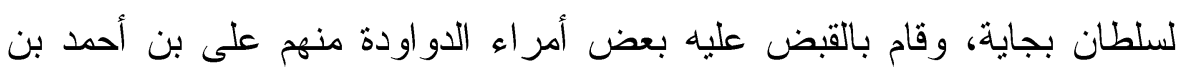

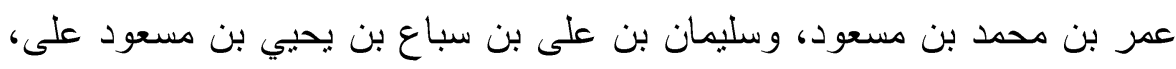

=تاريخ إفريقية فى العهد الحفصى، جr، صبه-OV؛ وحسب ابن خلدون كان صاحب

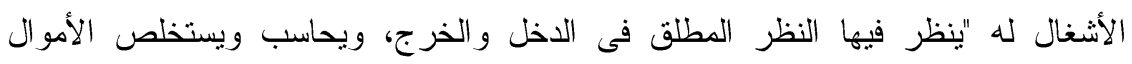

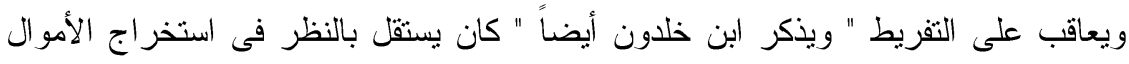

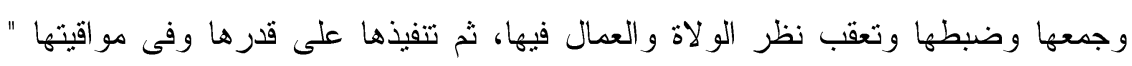

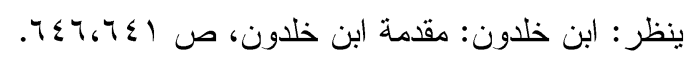

$$
\text { (1) (بوبار برنثفيك: المرجع السابق، ج)، ص } 101 .
$$

() سدويكش: عرفه لنا ابن خلدون " هذا الحى لهذا العهد وما قبله من العصور يعرفون

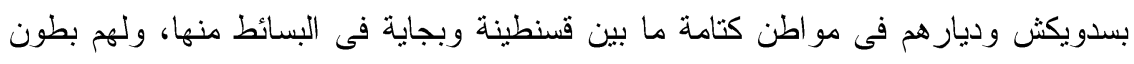

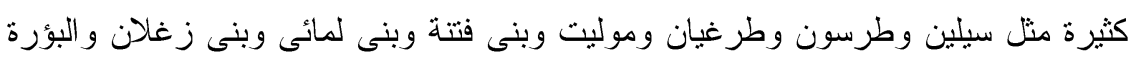

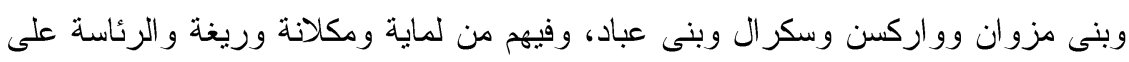

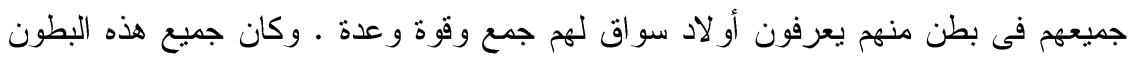

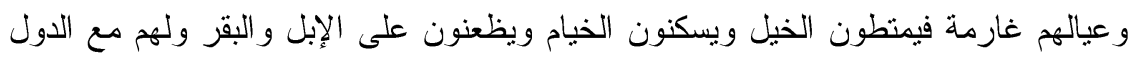

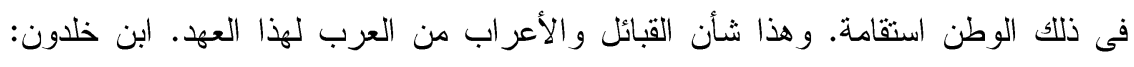

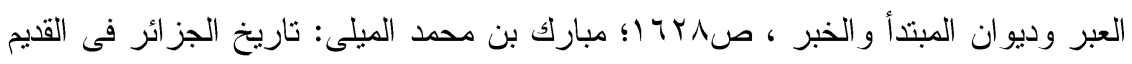

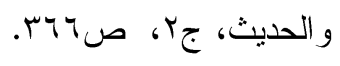

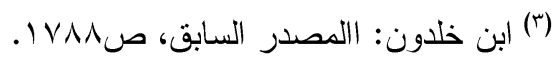


فقامو إعتقاله و هموا بقتله لو لا أن افتدى نفسه بخمسة قناطبر من الذهب، ومن حينها لم يتحرك منصور بن مزنى من مكانه إلا للضرورة:"(1). أدت كل تلك الأحداث إلى انساع نفوذ منصور بن مزنى وزيادة ثرائه،

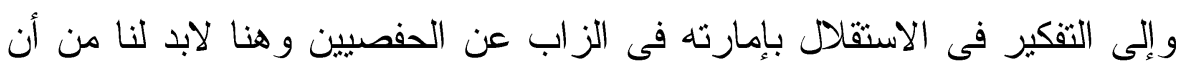
نعرف، كيف استطاع منصور بن مزنى الاستقلال بإمارته بالز اب عن الحفصيين؟ للإجابة على هذا السؤال لابد لنا أن نعرف فى البداية أن منصور بن مزنى النى

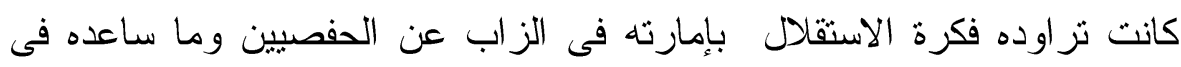
التفكير على ذلك بُعد مناطق حكمه عن السلطة المركزية، و انساع نفوذه،

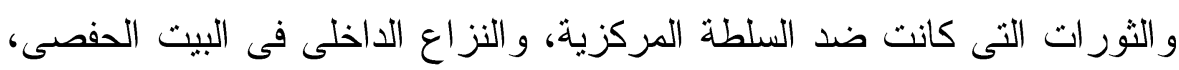

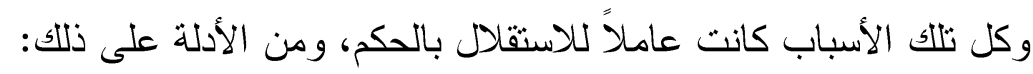

\section{1- بيعة منصور بن مزنى ليحيي بن خالد:}

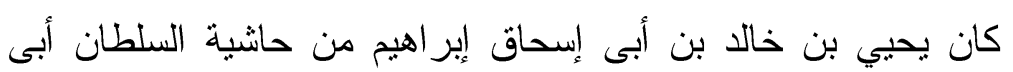

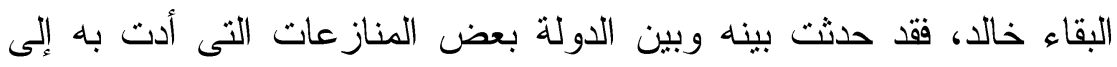

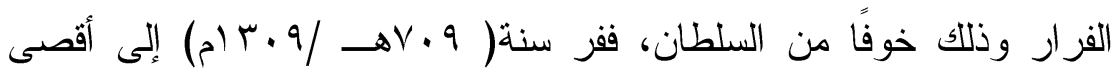

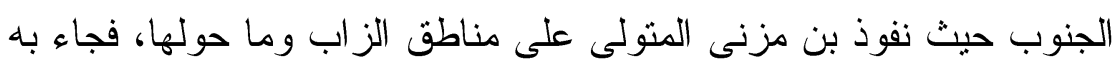

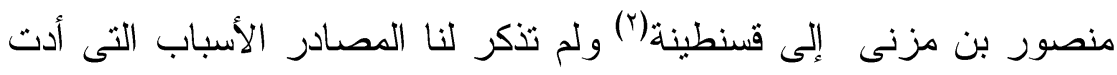

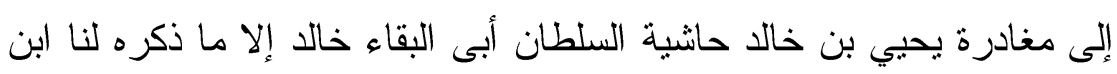

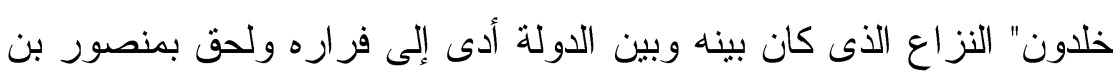

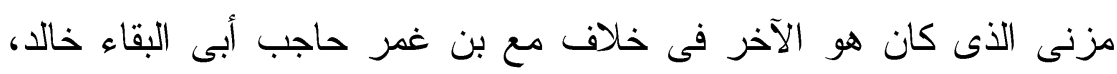

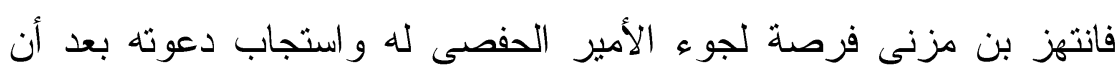

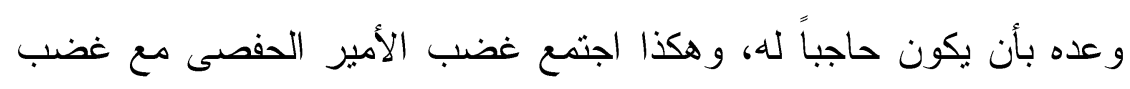

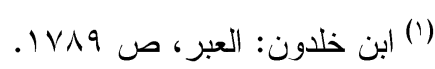

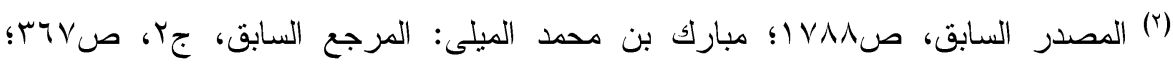
المطوى: السلطنة الحفصية، بالس. 
و الى مناطق الزاب فتعاونا على القبام بأول حركة انتفاضة تعثبر ضد الوحدة الحفصية.

ولكن ثلك الانتفاضة قضى عليها فى المهد، حيث اكتشف ابن مزنى أن هذا الأمبر الحفصى يُكن له الغدر بعد انتصاره على أبى البقاء خالد، و أند النه

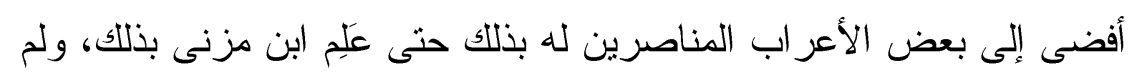

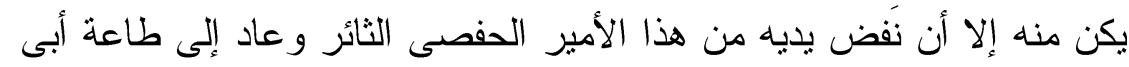

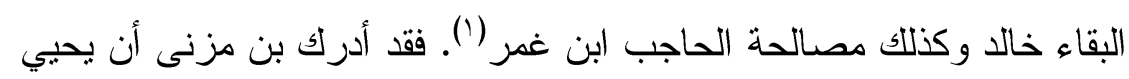

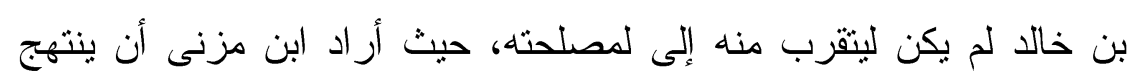
سياسة أبيه لنأييد ابن إسحاق فى الخروج ضد لئر أخيه المستتصر فيعود إليه

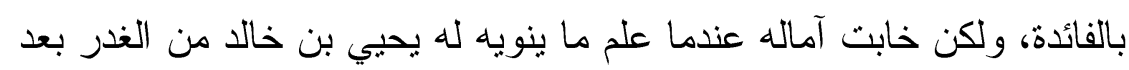

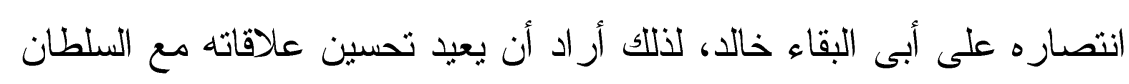
وكذلك الحاجب بن غمر . أما بحيي بن خالد اتجه إلى صاحب تلمسان أبى حمو موسى الأول،

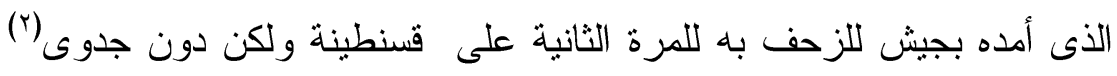

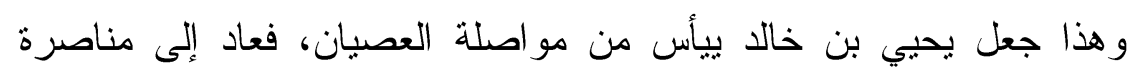

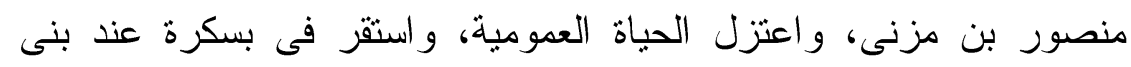

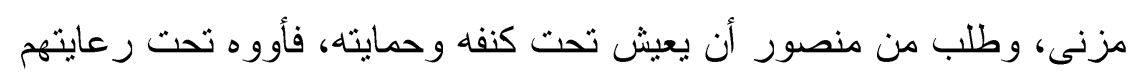

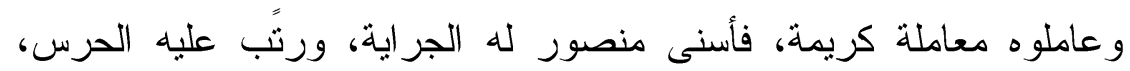
وكان السلطان اللحيانى الذى خلف أبى البقاء خالد فى حكم الحفصيين كان

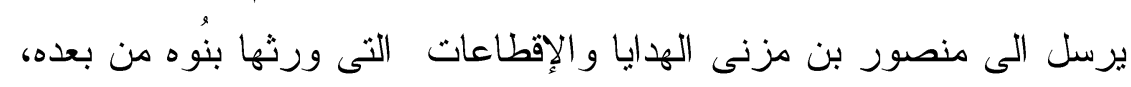

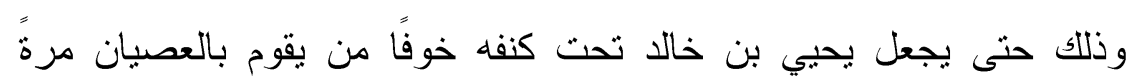

(1) المطوى: السلطنة الحفية، صب آب؛ الميلى: تاريخ الجزائر فى القديم والحديث، جr، صעיזי. (r) المرجع السابق، صץ ابس؛ روبار برنشفيك: تاريخ إفريقية فى العهد الحفصى، ج)، ص101. 
أخرى ضد السلطة الحفصية، وكذلك ظل بحي بن خالد فى بسكرة حتى توفى الى آنى

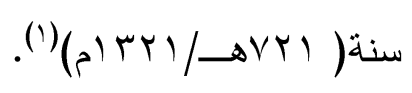

\section{r- مساندة منصور بن مزنى للزيانيين ضد السلطة الحفصية:}

خلال السنوات الأولى التى حكم فيها أبو بكر السلطنة الحفصية كانت تلك

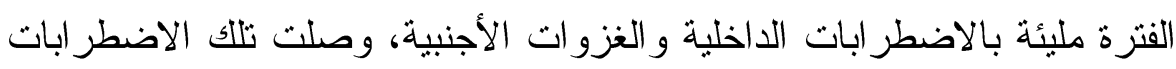

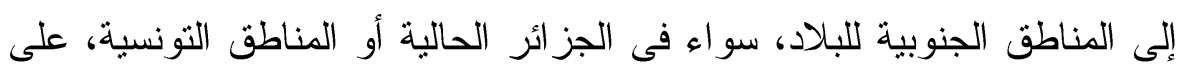

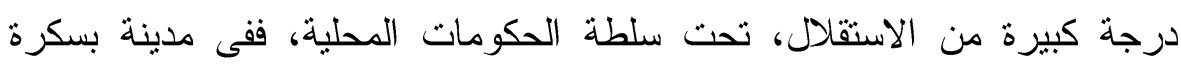
عاصمة إقليم الزاب خضع بنو مزنى الذين سيطروا على الواحات الصحراوية

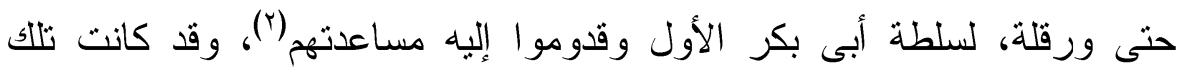

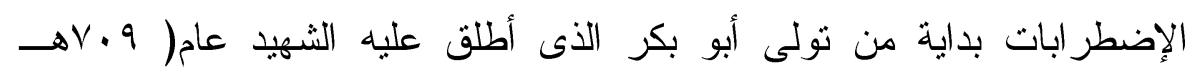

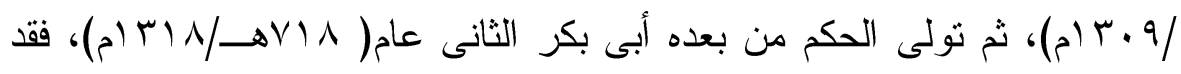

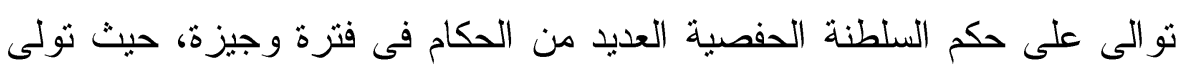

فى ثلك الفترة ما يقارب خمسة سلاطين، إضافة إلى حدوث التوثر فى بجاية(").

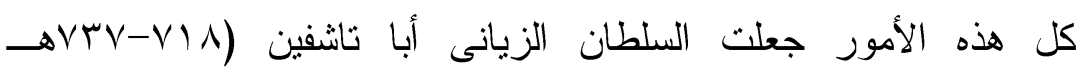

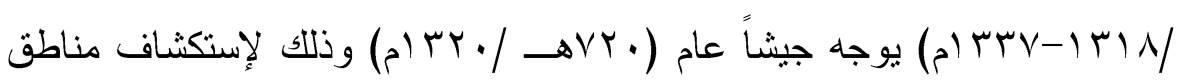

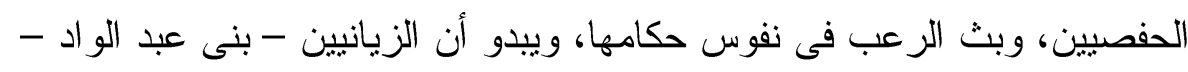
كانت لهم مطامع فى الإستيلاء على تونس و خير دليل على ذلك مساعدتهم ليحي لئي

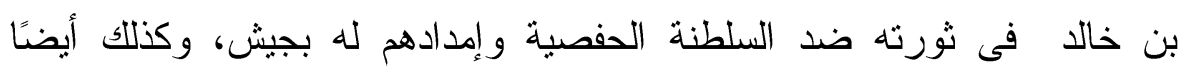
مساندتهم للثور ات التى كانت هدفها إثارة القلق فى نفوس الدولة الحفصية ومنها ثورة سعادة الرحمانى التى سنقوم بذكرها بشكل مباشر وموسع، فقامو ابإسال

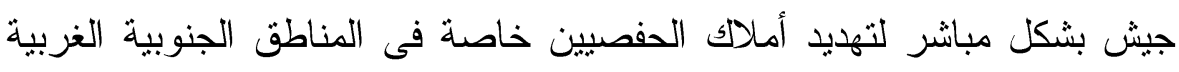

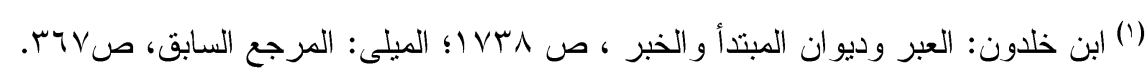

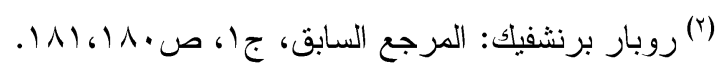

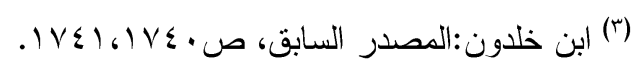


حيث اتجه إلى بجاية وقسنطينة، وأمر أبو تاشفين قائده ببناء مدينة على وادى

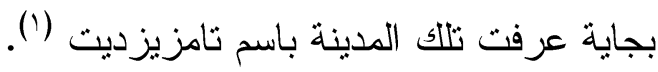
فسارع منصور بن مزنى إلى بنى عبد الواد واعترف بتبعيته لهم وذلك

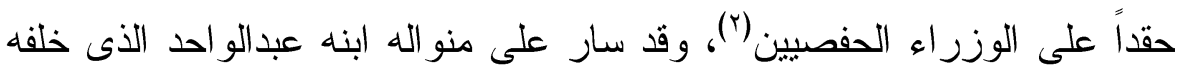
سنة (VTO

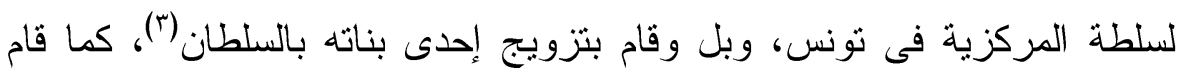

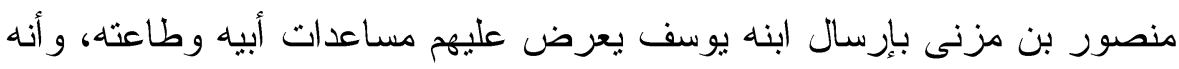

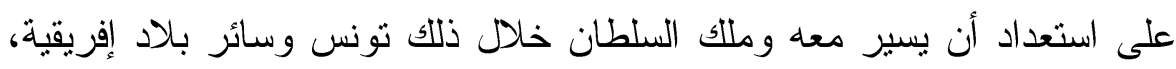

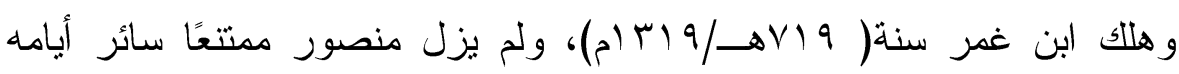
على الدولة)(

أدت مساعدات منصور بن مزنى للزيانيين إلى تهديدهم للأملاك الحفصية

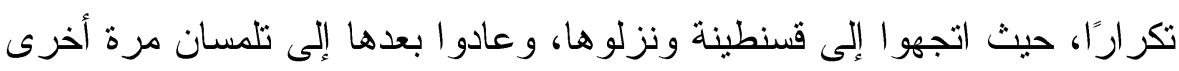

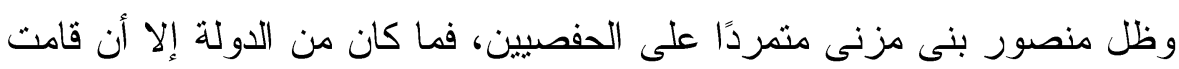

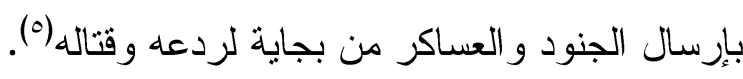

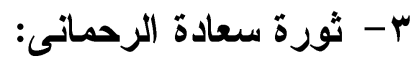

(1) يحيي بن خلدون: بغية الرواد فى ذكر الملوك من بنى عبدالواد، صهـ ا؛ التتسى : تاريخ

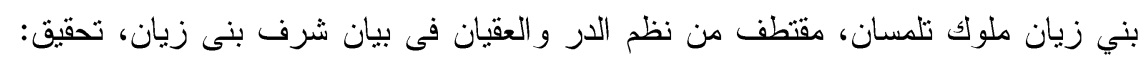

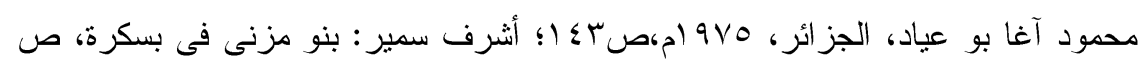

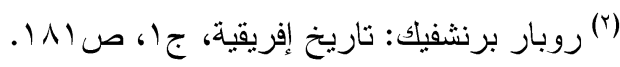

$$
\begin{aligned}
& \text { (") المرجع السابق: ج(،ص الما. }
\end{aligned}
$$

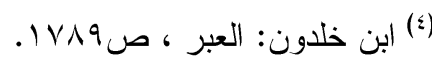

(0) الميلي: تاريخ الجزائر فى القديم والحديث، جr، صلآس؟؛ عادل نويهض، معجم أعلام

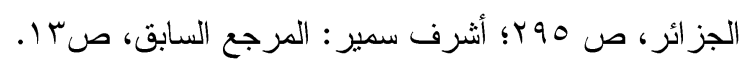




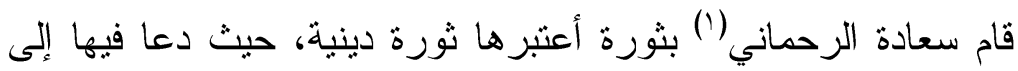

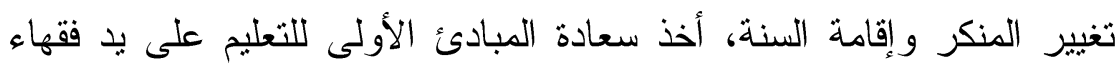

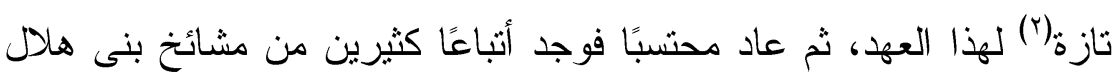

(') سعادة الرحماني: هو رجل مسلم من إحدى شعوب رياح، ثث رحمان الرياحية، كانت أمه

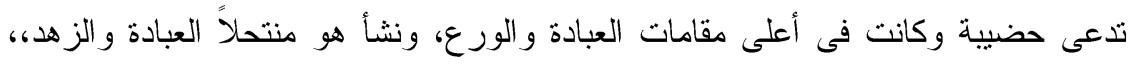

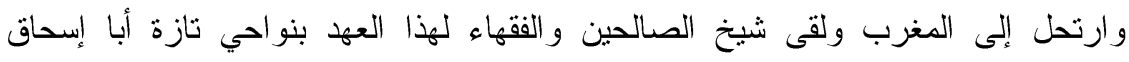

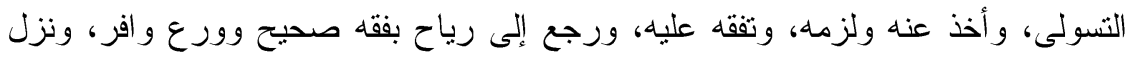

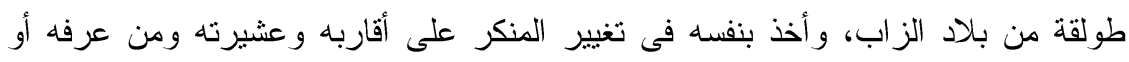

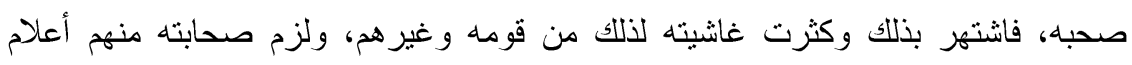

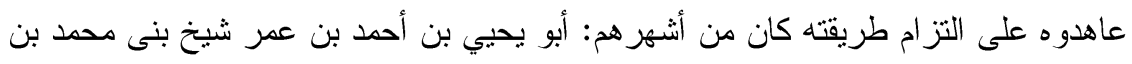

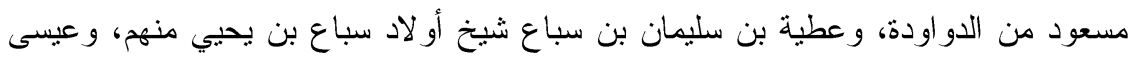

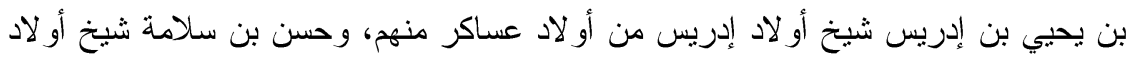

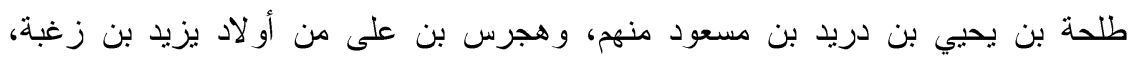

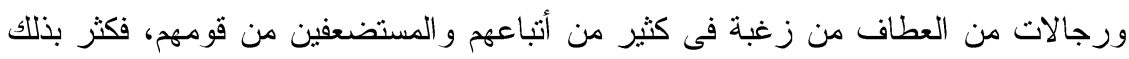

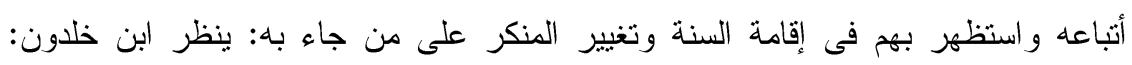

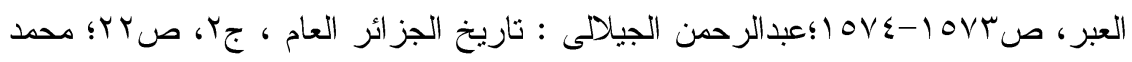

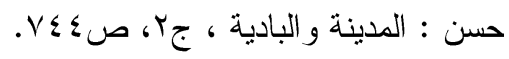

() تازة: مدينة كبيرة لا يقل شرفها عن قوتها، وتتميز بموقعها الاستراتيجى الهام فهى حلقة

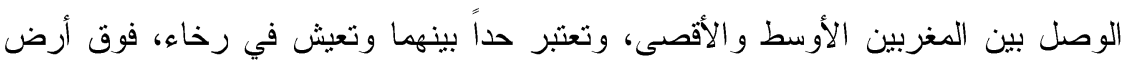

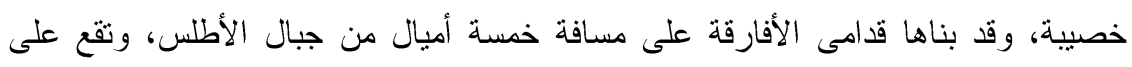

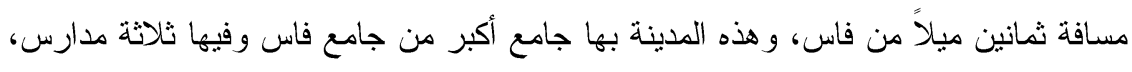

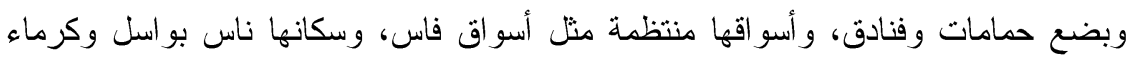

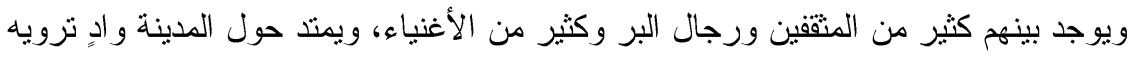

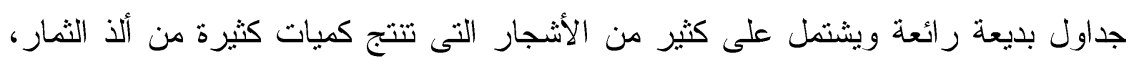

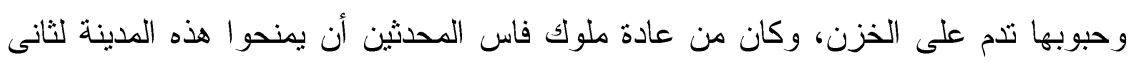

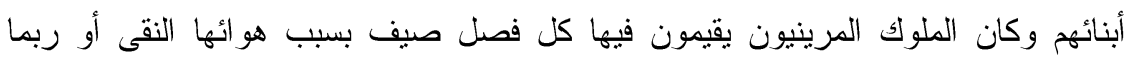

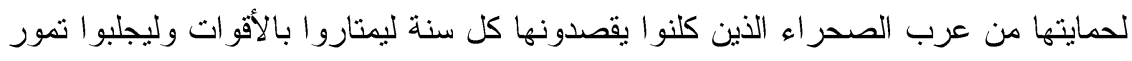

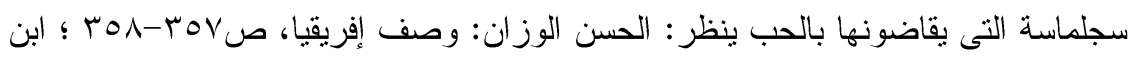

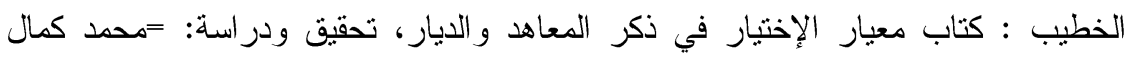

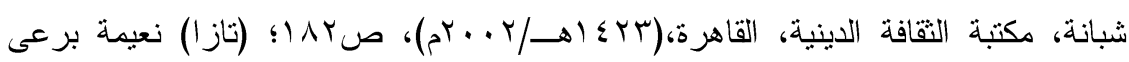


وعامتهح وأصبحو ا يعرفون بالسنية (') و اتخذ من مدينة طولقة مقرًا لله

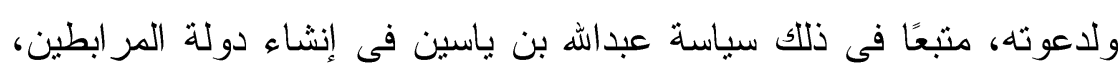

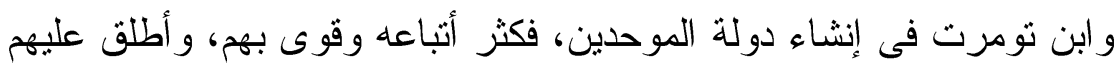

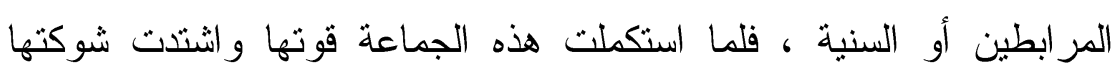

أخذت فى شن الغار ات على الهاربين وقطاع الطرق آمان.

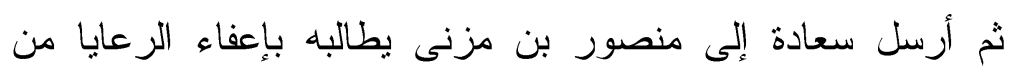

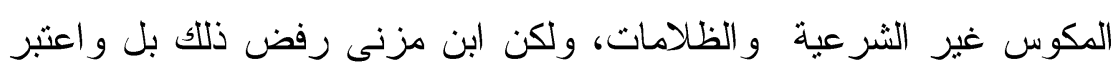

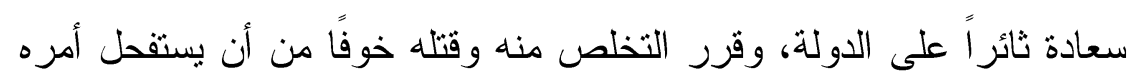

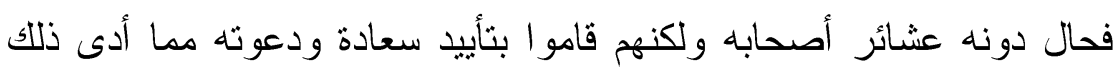

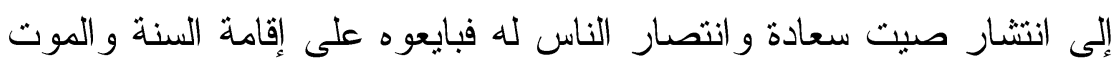
دون ذلك، فأرسل إلى السلطان أبى البقاء خالد و الىى بجاية يطالبه بالمدد

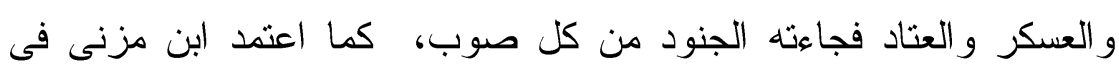
حربه مع سعادة على كبار شيوخ الدواودة و على الجنود النظاميين الو افدين

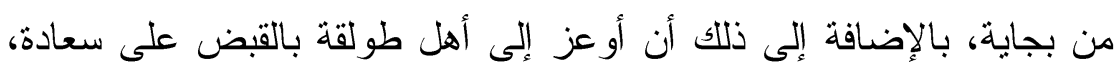

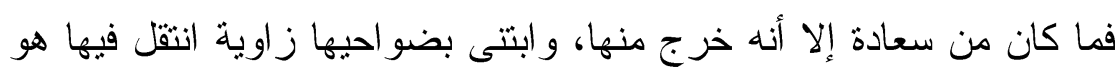
و أصحابه و اتخذها قاعدة بنطلق منها فى حروبه ضد ابن ابن مزنى و أتباعه، ثم

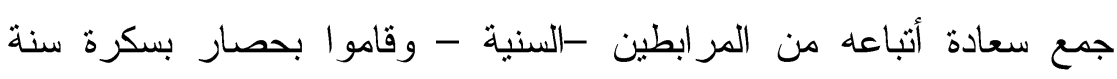

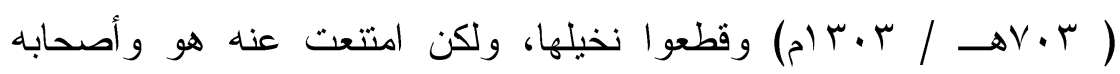

=

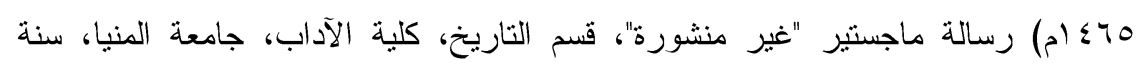

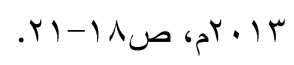

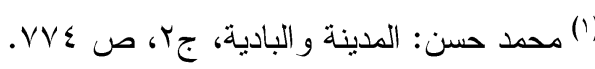
(؟) ابن خلدون: العبر، صع 10V؛؛ عبد الرحمن الجيلالى: تاريخ الجزائر العام، جr، صسr. 


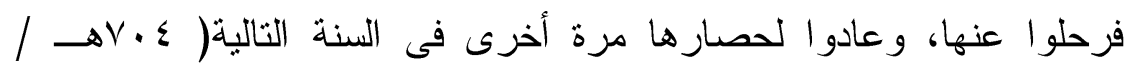
ع . بام)، ولكن دون جدوى (1). ولكن يجب علينا التساؤل هنا: لماذا لم يزحف أمير الز اب لقتال سعادة

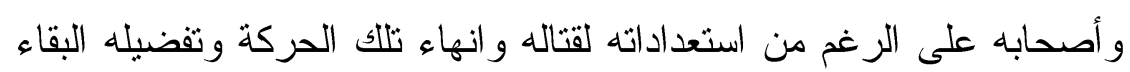
فى بسكرة؟

ربما بظن القارئ فى بادئ الأمر أن ذلك تقصير من أمير الزاب وعدم

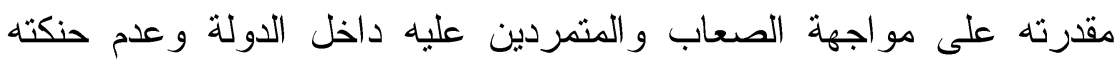

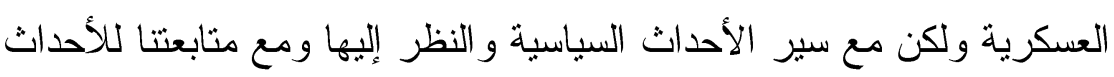

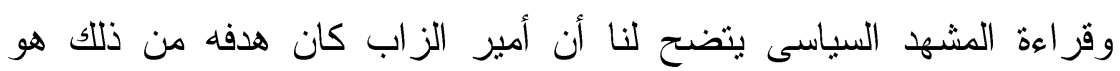

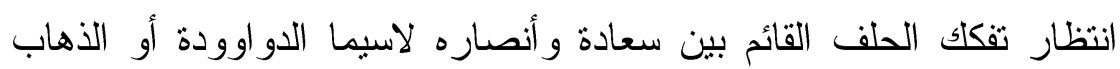

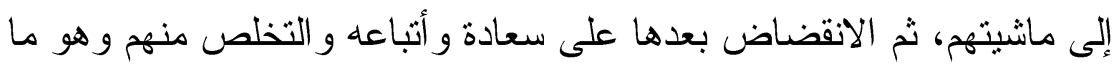

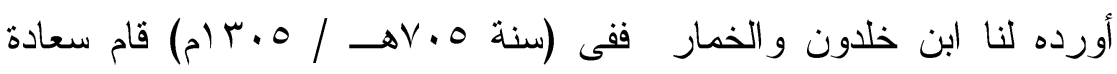

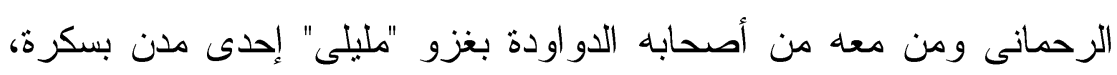

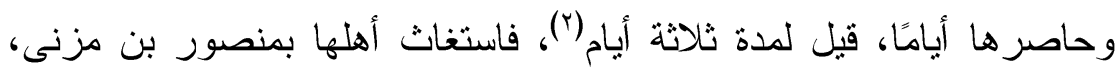
فأرسل إليهم جيشًا يتألف من العسكر السلطاني، وبعض القدائل القبائل العربية

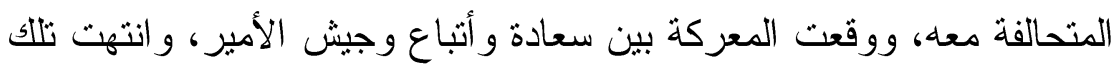

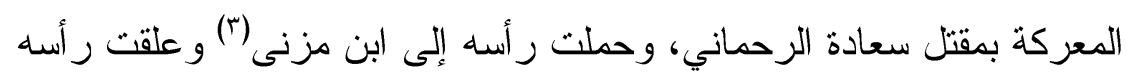
فوق منارة المسجد الكبيز ببسكرة:(\&).

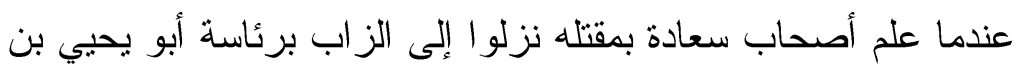

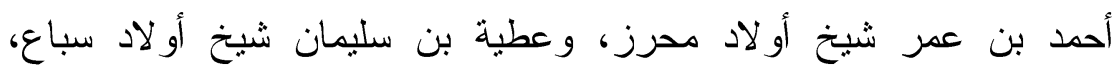

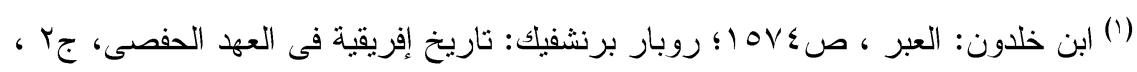

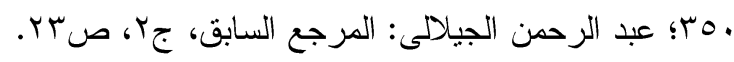
(() احمد خمار : تحفة الخليل في نبذة من تاريخ بسكرة النخيل، صلV.

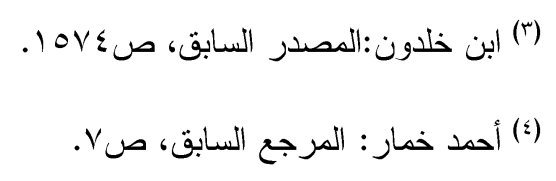


وعيسى بن يحبي شيخ أولاد عساكر، ومحمد بن حسن شيخ أولاد عطية،

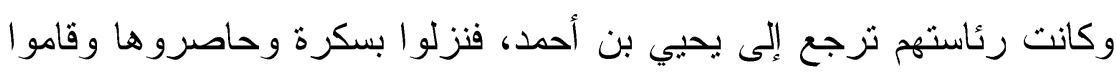

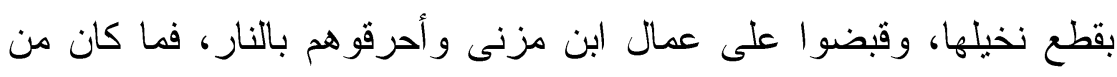
ابن مزنى إلا أن جمع حلفاءه من بطون العرب أمثال على بن أحمد شيخ

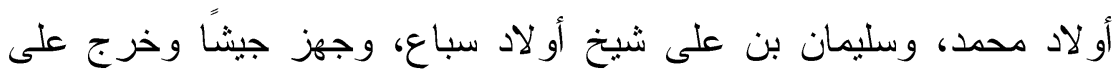

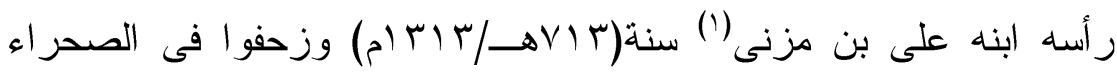
ودارت رحى الحرب بين الطرفين انتهت بمقتل على بن مزنى، فقد وجدوه

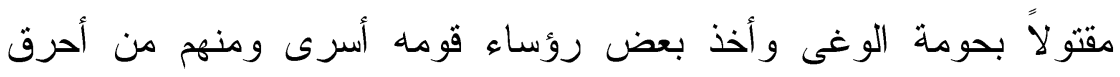

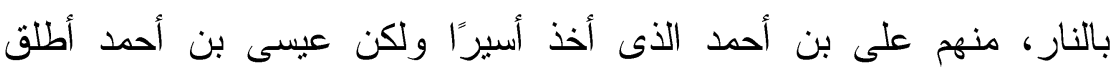

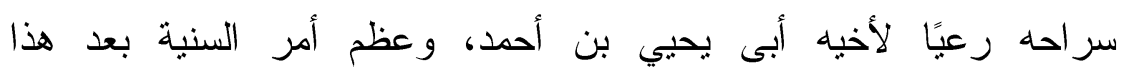

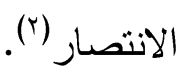

بعد وفاة أبى يحيي اختار "السنية" زعيمًا روحيًا لهم هو عبداله بن محمد بن الأزرق من فقهاء مقرة، الذى سوف نتحدث عنه تفصيلاً أثناء

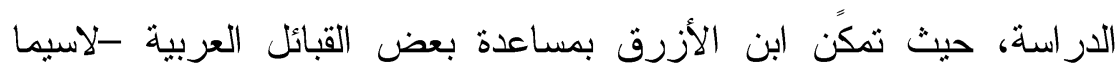

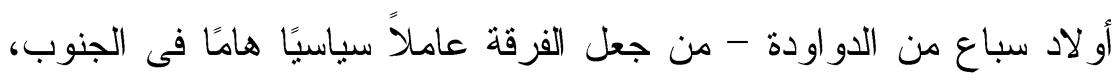

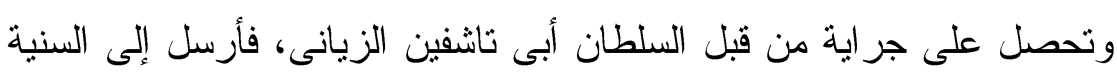

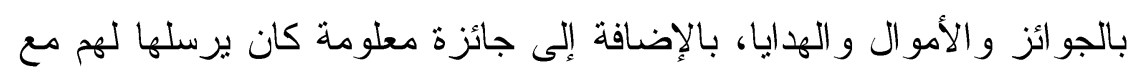

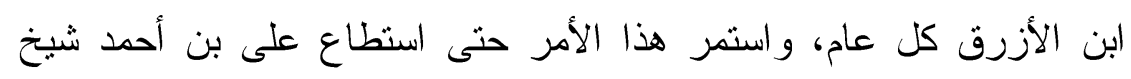

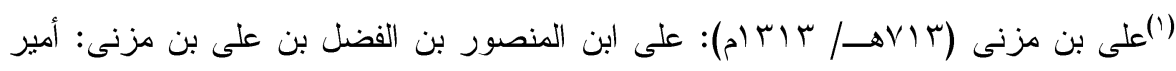

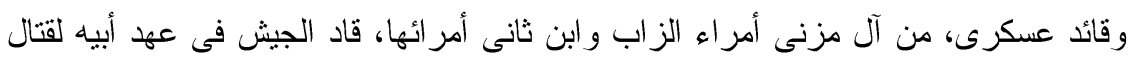

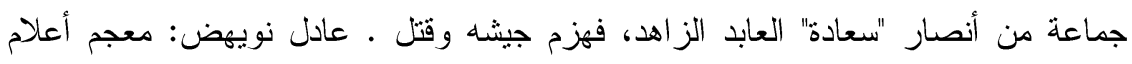

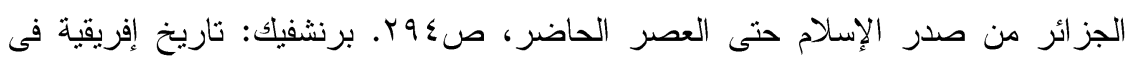

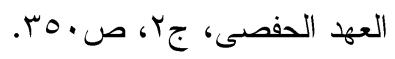

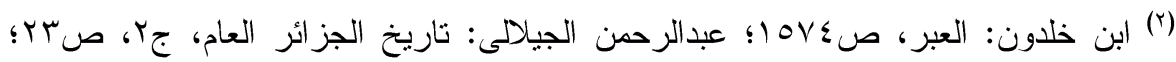

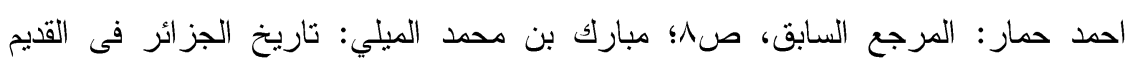

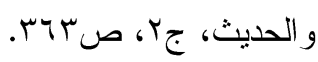


أولاد محمد حيث ضعف أمرهم، فما كان من الأزرق إلا أن التجأ ابن الأزرق إلى يوسف بن مزنى ببسكرة الذى استذعاه ليتولى قضاء بسكرة،

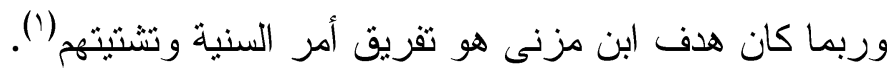

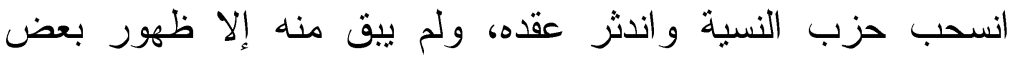
الزعماء الذين و اصلو ا نشاطهح وتداخلت لديهم الأغر اض الدينية مع الدنيوية.

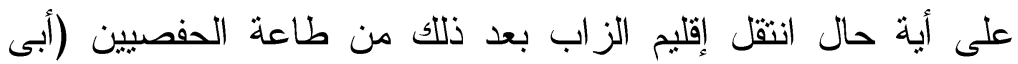
يحيي أبى بكر) إلى طاعة وتبعية بنى عبد الو اد (أبى تاشفين)، و استمر إقليم

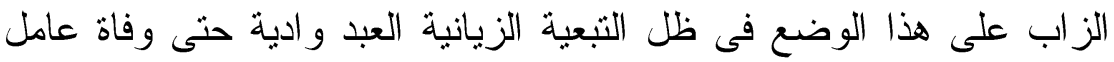

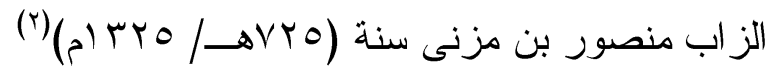

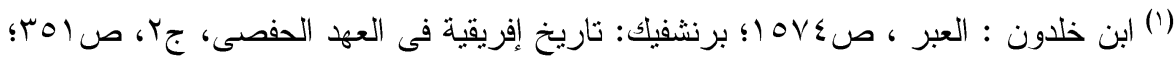

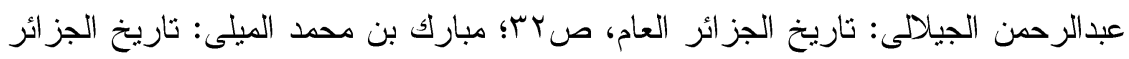

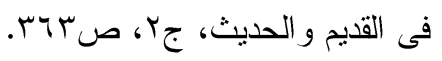

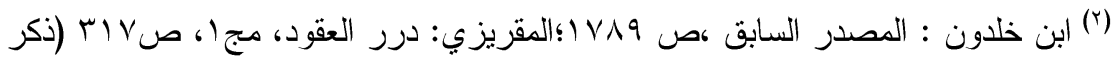

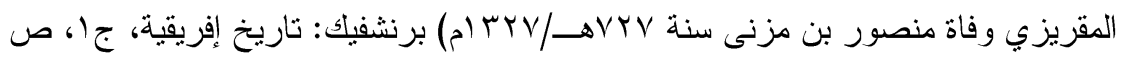




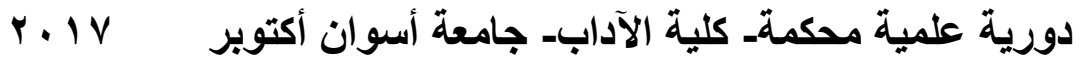

قائمة المصادر والمراجع

$$
\text { أوثًا :-المصادر العربية }
$$

الإدريسى(أبو عبدالله محمد بن محمد المعروف بالثريف الإدريسى

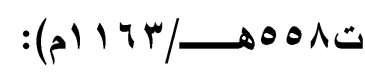

-المغرب فى ذكر السودان ومصر و الأندلس من كتاب نزهة المشتاق فى إختر قاق الآفاق، مطبعة ليدن، كوما ا.

الباجى المسعودى(محمد الباجى بن أبى بكر المسعودى البكرى ت ت :( $) \wedge \vee q /$ ( ) rqv

- الخلاصة النقية فى أمر اء إفريقية ، تقديم وتحقيق وتعليق محمد زينهر محمد

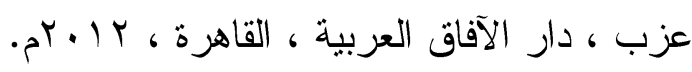

البكرى (أبو عبيد الله عبد الله بن عبد العزيز بن أيوب ت NV هـ/ـ 9 ـ ام): - المغرب فى ذكر بلاد إفريقية و المغرب وهو جزء كتاب المسالك و الممالك، دار الكتاب الاسلامى ، القاهرة (د.ت).

التنسى(محمد بن عبد الله التنسى ت 199هـ// ؟ ؛ ام):

- تاريخ بنى زيان ، مقتطف من نظم الدر و العقبان فى بيان شرف بنى زيان

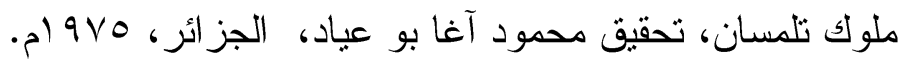

الحميرى(أبو عبد الله محمد بن عبد الله عبد المنعم الصنهاجى $:$ : (م)

-الروض المعطار فى خبر الأقطار ، معجم جغر افى مع فهارس شاملة ، تحقيق

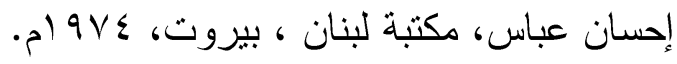




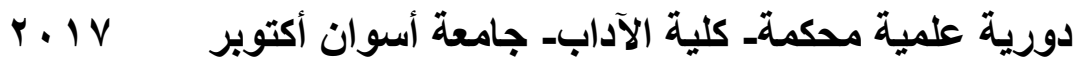

--ابن خلاون(أبو زيد عبد الرحمن بن محمد بن جابر بن إبراهيم بن

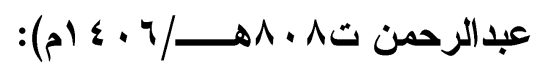

-العبر وديوان المبتدأ والخبر فى أيام العرب و العجم و البربر ومن عاصرهم من

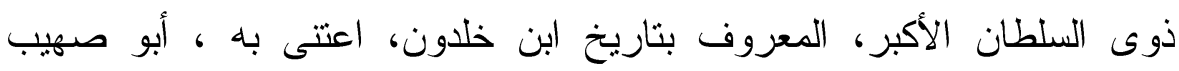
الكومى، دار الأفكار الدولية ، (د.ت).

-مقدمة ابن خلدون، حقق نصوصد، وخرج أحاديثه ، و علق عليه: عبداله محمد

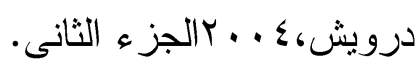

ابن الخطيب (أبو عبد الله محمد بن عبد الله بن سعيد بن على بن أحمد

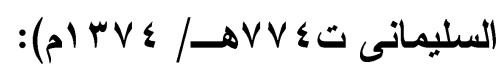

- معيار الاختيار فى ذكر المعاهد و الديار ، تحقيق ودر اسة محمد كمال شبانة ،

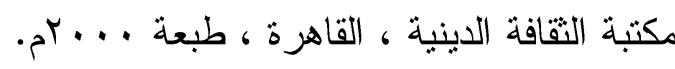
الزركثى(أبو عبد الله محمد ابن إبراهيم ت بrوهـــ/O ام ) )

- تاريخ الدولنين الموحدية و الحفصية ، تحقيق محمد ماضور ، الطبعة

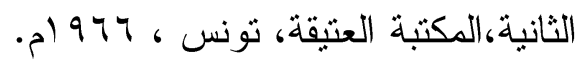

(بن سعيد المغربى(أبى الحسن على ابن موسى بن سعيد المغربى

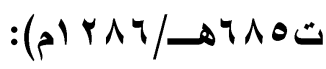

-كتاب الجغر افيا، حققه إسماعيل العربى، الطبعة الأولى، المكتب التجارى

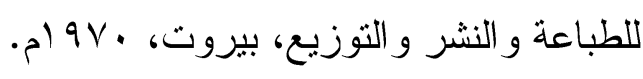

ابن سباهى زادة( محمد بن على البروسوى الثهير بابن سباهى زادة ت

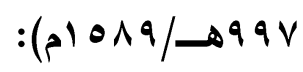

- أوضح المسالك فى معرفة البلدان و الممالك ، تحقيق المهدى عبد الرواضية ،

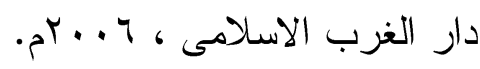




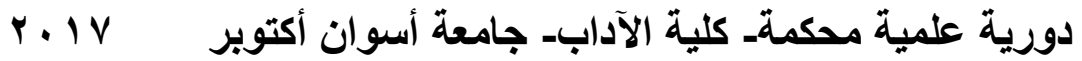

ابن عبد الحق البغدادى (صفى الدين عبد المؤمن بن عبد الحق البغدادى الحلبى

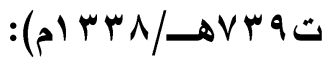

-مراصد الإطلاع على أسماء الأمكنة و البقاع ،الطبعة الأولى، دار الجيل ، بيروت، r إ أهـ.

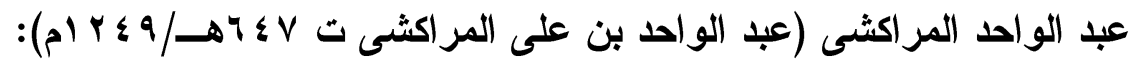
- المعجب فى تلخيص المغرب، تحقيق محمد زينهم محمد عزب، دار الفرجانى

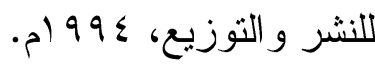

المقريزى(تقى الدين أحمد بن على المقريزى ته ؛ 1هـ/ ؟ ؛ ام):

-درر العقود الفريدة فى تزاجم الأعبان المفيدة، المجلد الأول، حققه وعلق عليه

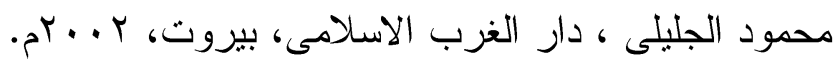

-إتعاظ الحنفا بأخبار الأئمة الفاطبين الخلفا ، تحقيق : جمال الدين الشيال، الجزء الثانى، المجلس الأعلى للشئون الاسلامية، 997 إم.

مؤلف مجهول كاتب مراكثى من كتاب القرن السادس الهجرى/الثانى عشر الميلادى:

-الاستبصار فى عجائب الأمصار، نشر وتعليق سعد زغلول عبد الحميد ، دار النشر المغربية ، الدار البيضاء، 910 إم. الورثيلانى(سيدى الحسين بن محمد الورثيلانى ت 9 ا أهـ/PV9 ام): - الرحلة الورثنانية المسماة نزهة الأنظار فى فضل علم التاريخ والأخبار،

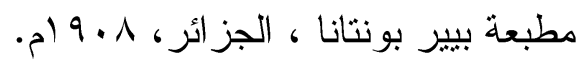

الوزان(الحسن بن محمد الوزان الفاسى المعروف بليون الأفريقى عاش فى

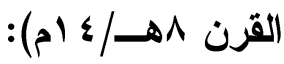




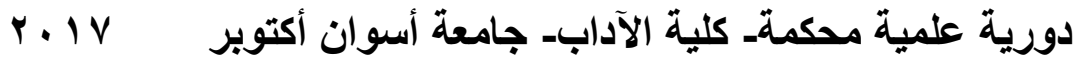

-وصف أفريقيا ، تزجمه من الفرنسية محمد حجى، محمد الأخضر، الطبعة

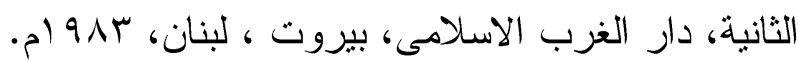

ياقوت الحموى( شهاب الدين أبى عبد الله بن أبى عبد الله الرومى البغدادى ت

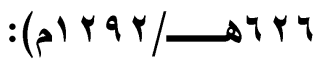

- معجم البلدان ، المجلدات الأول و الر ابع و الخامس، دار صادر بيروت. يحيي بن خلدون( أبى زكريا يحيي ابن أبى بكر محمد بن محمد بن محمد بن

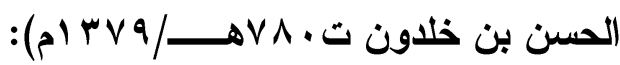

-بغية الرواد فى ذكر الملوك من بنى عبد الواد ، المجلد الأول، مطبعة بيير

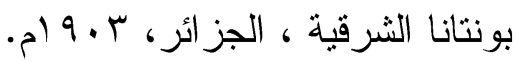

ثانيًا:-المر اجع العربية

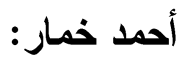

-تحفة الخليل فى نبذة من تاريخ بسكرة النخيل ، دار الهدى ، عين مليلة،

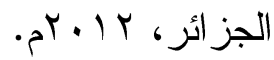

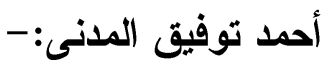

-كتاب الجزائر، تاريخ الجزائر الى يومنا هذا وجغر افيتها الطبيعية و السياسية

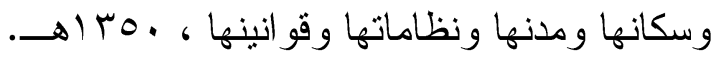

إسماعيل العربى:

-الصحر اء الكبرى وشو اطئها ، المؤسسة الوطنية للكتاب ، الجزائر ، ب19 ام. أمين و اصف:

الفهرست" معجم الخريطة التاريخية للممالك الإسلامية " ، مر اجعة أحمد زكى ، مؤسسة هنداوى، 1917 (م. 


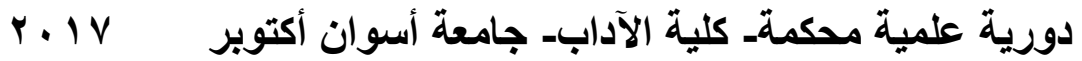

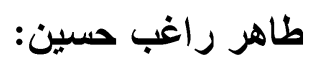

- التطور السياسى للمغرب من الفتح الاسلامى الى آخر القرن العاشر الهجرى،

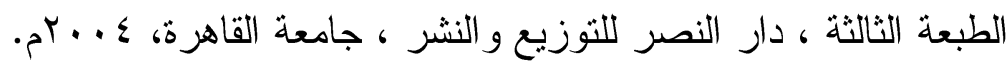

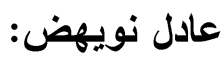

-معجم أعلام الجزائر منذ صدر الاسلام حتى العصر الحاضر، الطبعة

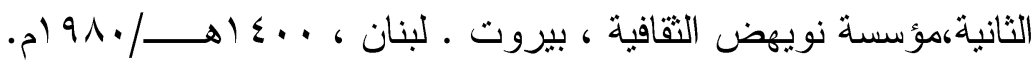
عبد الحكيم العفيفى: - n -موسوعة . . عبد الحليم صيد: - أبحاث فى تاريخ زيبان بسكرة ، مطبعة سوف. عبد الحميا بورابوين: -القصص الشعبى فى مدينة بسكرة (در اسة ميدانية)، المؤسسة الوطنية للكتاب،

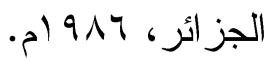
عبد الرحمن بن محمد الجيلالى :

-تاريخ الجزائر العام ، الجزء الثانى، دار مكتبة الحياة ، بيروت، مكتبة الشركة الجز ائرية ، الجزائر، الطبعة الثانية ، 970 أم.

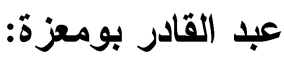

- بسكرة فى عيون الرحالة الغربيين ، الجزء الثانى ،الطبعة الثانية، مدن

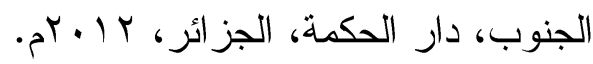




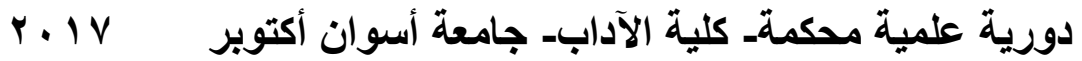

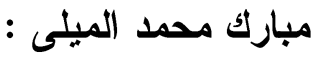

- تاريخ الجز ائر فى القديم و الحديث ، الجزء الثانى ، تقديم وتصحيح محمد الميلى ، المؤسسة الوطنية للكتاب .

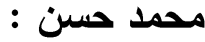

-المدينة و البادية بإفريقية فى العهد الحفصى ، الجزء الثانى، جامعة تونس الاولى، 9.9

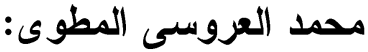

- السلطنة الحفصية تاريخها السياسى ودورها فى المغرب الاسلامى، دار الغرب

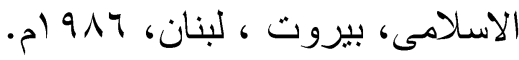

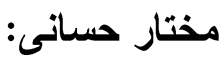

-موسوعة تاريخ وثقافة المدن الجزائرية / الجزء الثانى، مدن الجنوب، دار

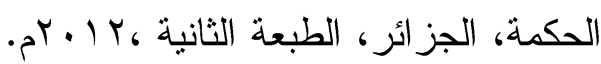

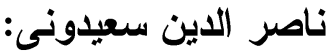

- من التزراث التاريخى و الجغر افى للغرب الاسلامى " تر اجم مؤرخين ورحالة جغر افين " دار الغرب الاسلامى ، بيروت ، 991 ام.

بسكرة أسوار من حضارة : وزارة الثقافة ، الجزائر.

ثالثًا: الاوريات

أشرف سمير توفيق

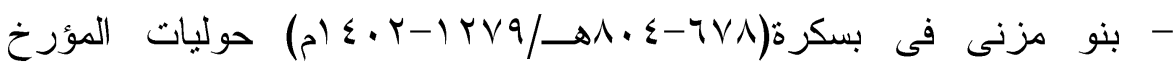
المصرى ، جامعة القاهرة ، كلية الآداب ، فبر اير 17 • بـم . 


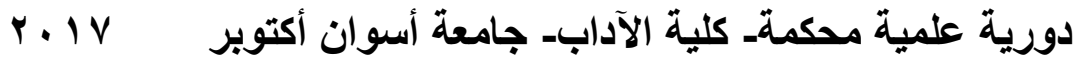

فوزى مصمودى:

-بسكرة عروس الزيبان وبوابة الصحراء ، بسكرة، الجزائر، مجلة الفيصل،

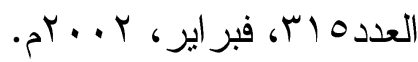

رابعًا:-الرسائل العلمية

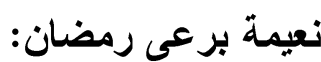

- مدينة تاز ا تاريخها السياسى و الحضارى،(VY) رسالة ماجستير، "غير منشورة"، جاكمعة المنيا، كلية الآداب ، قسم التاريخ ، $\cdot 5 r \cdot 1 r_{6}$

خامسًا: المراجع المعربة

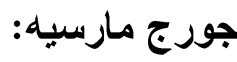

-بلاد المغرب وعلاقاتها بالمشرق الاسلامى فى العصور الوسطى، نرجمة

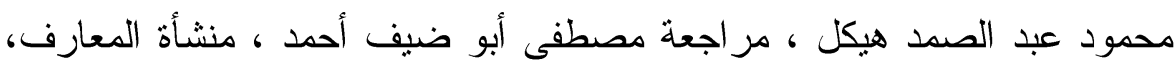

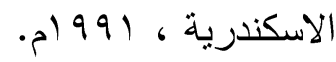
روبار برنشفيك:

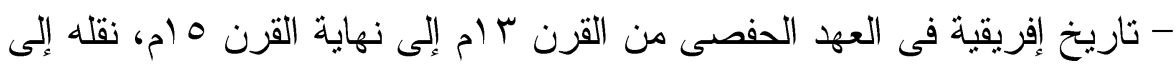

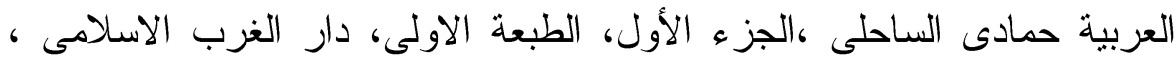
. $9 \wedge \wedge$ سادساً: المراجع الأجنبية :- (-

1)Marc cote:

La ville et le desert Le Bas- Sahara Algerien, Paris. 